\author{
Cruise Report \\ $w-41$ \\ Scientific Activities \\ Woods Hole-Bermuda-Lunenberg-Boston \\ July 26 - September 6, 1978 \\ $\mathrm{R} / \mathrm{V}$ Westward \\ Sea Education Association \\ Woods Hole, Massachusetts
}
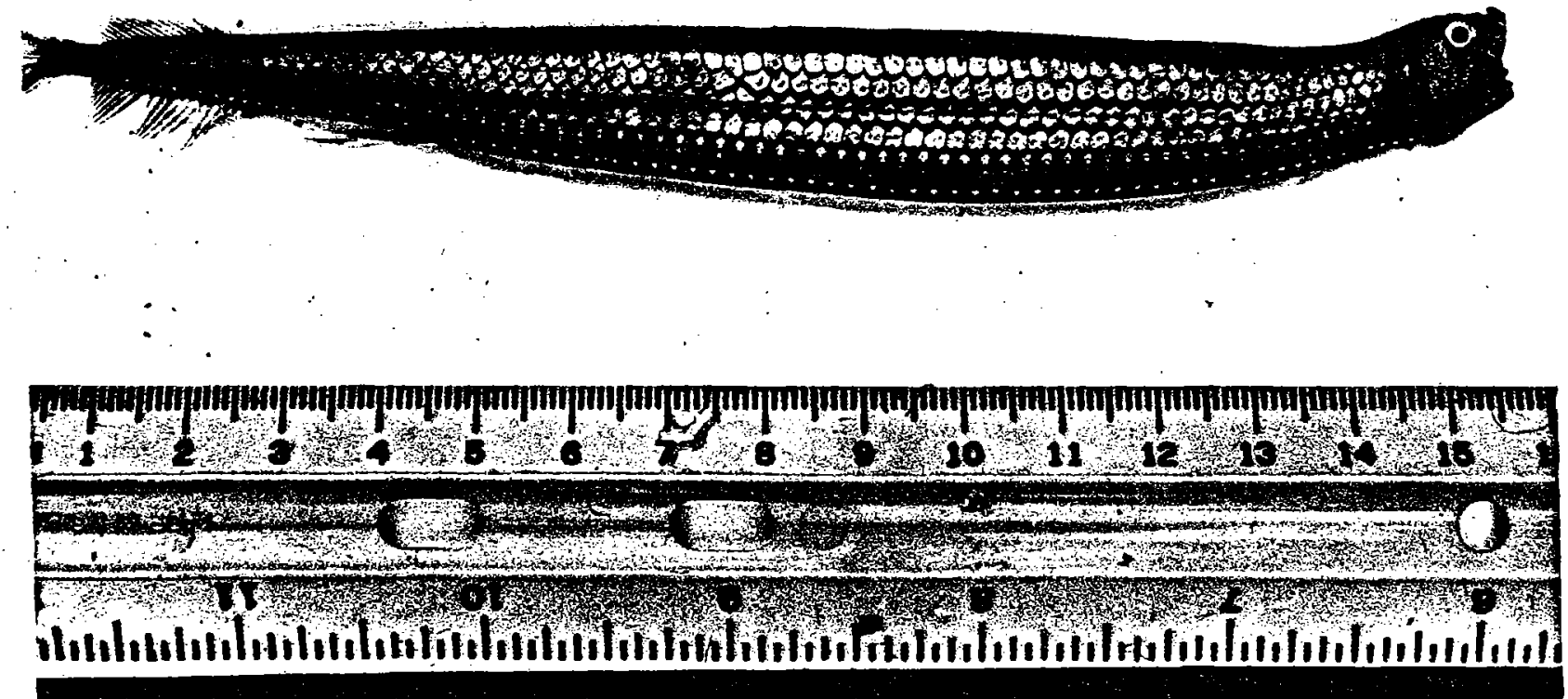


\section{Introductory Preface}

This report documents the scientific education and research programs undertaken on the $41^{\text {st }}$ cruise of the $R / V$ Westward under direction of Sea Education Association, Woods Hole, Mass. Primary among our purposes on this six week cruise was to give its twenty-three students a multidisciplinary exposure to oceanographic concepts and research techniques, drawing on the various backgrounds of the staff and the sampling equipment on board. To this end, students were offered a wide range of relevant lecture material and on watch instruction; they were required to participate as assistants in staff directed research, as well as accomplish a personal research project of their own design. This program thus comprises Boston University Course NS CLX 225, Introduction to Marine Science Laboratory.

Due to constraints on time, results of all research efforts are presented mainly in abstract form, the state of data reduction and interpretation remaining essentially as it existed at the end of the cruise. The main body of the report contains overviews of cooperative, in-house and visiting investigator research activities, accompanied by related student reports. Sumaries of major stations, tabulated and graphed data, a cruise track and details of the academic program appear in appropriate sections and in appendices.

No cruise of this type would be a success without the aid of a talented supporting staff. It has been a genuine pleasure to work with Dr. Mary Farmer, Miss Molly Allison, and Miss Abigail Ames, all members of S.E.A.'s permanent scientific staff. Miss Patricia McGill, Mr. Edward Robb, and Mr. Timothy Rumage all made stimulating contributions as visiting investigators. The ship's nautical staff, notably her alternate captains, Mr. Jonathan Lucas and $\mathrm{Mr}$. Richard Farrell, deserve special thanks for their cooperation and competent management of the cruise.

Research conducted on $W-41$ partly represents the ongoing work of individuals and agencies that have extended their assistance to our students. Material reported herein should not be excerpted or cited without the written permission of the Chief Scientist.

Carl M. Baum

Chief Scientist

September 25, 1978 
Table of Contents

Introductory Preface

Table of Contents

Cruise Itinerary

Cruise Track

Ship's Complement

Academic Program

(page)

List of Lectures and Seminars

Overview of Research and Study Activities

I. Cooperative Programs

A. Cooperative Ship's Weather

Observation Program (NOAA)

B. Shark Tagging by Long Line (MMFS)

II. In-House Research

A. Zoogeography of Western North Atlantic

Midwater Fauna

1) Distribution of Myctophid Genera (Rand)

2) Gulf Stream Edge Effect (Davis)

B. Diel Periodicity in the Western North Atlantic

1) Vertical Migration in Midwater Fish (Sanentz)

C. Distribution of Anguilli form Ieptocephalus Larvae in the Western North Atlantic

1) Family Diversity in Anguilliform Leptocephalus Larvae (Hatch and Owen)

D. Distribution and Acoustics of Marine Mammals in the Western North Atlantic

1) Baleen Whale Distribution and Zooplankton Abundance (Deutsch)

2) Photographic Identification of Whales (Belisle)

3) History of Whaling (McAlpin)

4) Whaling Legislation (Letelier)

E. Investigations into the Neuston and Sargassum Communities

1) Neuston Fish Diversity (Ziewacz)

2) Morphological Adaptations in Neuston Fish (Thebault)

3) Sargassum Weed Standing Crop (LaParI) 21

4) Sargassum Macrofauna Diversity (Reese)

5) Biology of the Sargassum Fish, Histrio histrio (Baum)

F. Island Mass Effects on Phytoplankton Communities

(Farmer)

G. Physical and Chemical Comparison of Major Water

Masses in the Western North Atlantic

1) Temperature - Salinity Profiles (Howerton and Hodges)

2) Nutrient Profiles (Llewellyn and Robbins) 27

3) Secchi Disc and Submarine Photometry (Glasser) 28

4) Surface Temperature Effects on Weather (Morss) 
Table of Contents (Cont.)

H. Miscellaneous Studies and Investigations 30

1) Coral Reef Fish Observations 30

2) Epibenthos of the Continental Shelf - 30

3) Life Boat Navigation Technique (Gandrup and
Valpey)

III. Visiting Investigators $\quad 30$

A. Seabird Studies 30

1) Seabird Observations from Four Central Atlantic Water Masses (McGill) 31

2) Population Dynamics of Pelagic Birds (Rumage) 32

3) Effects of Water Mass Productivity on Seabird Diversity and Density (Steiner and Quintrell) 32

B. Pathology of Pèlagic Fishes (Robb) 34

Appendices

1) Summary Logs of Major Stations 35

2) The Biological Teaching Collection 39

3) Ship's Weather Observations 40

4) Marine Mammal Sightings 41

5) Coral Reef Fishes at Castle Rock, Bermuda 43

6) Otter Trawl Species Rosters 44

7) Hydrographic Data Log 45

W-4I Geographic Itinerary

26 July
Leg I
08-10 August
Leg II
23-26 August
Leg III
06 September depart Woods Hole 800 miles

St. George's Harbor, Bermuda 1100 miles

Lunenberg, Nova Scotia 500 miles

arrive Boston

Total miles: 2400 


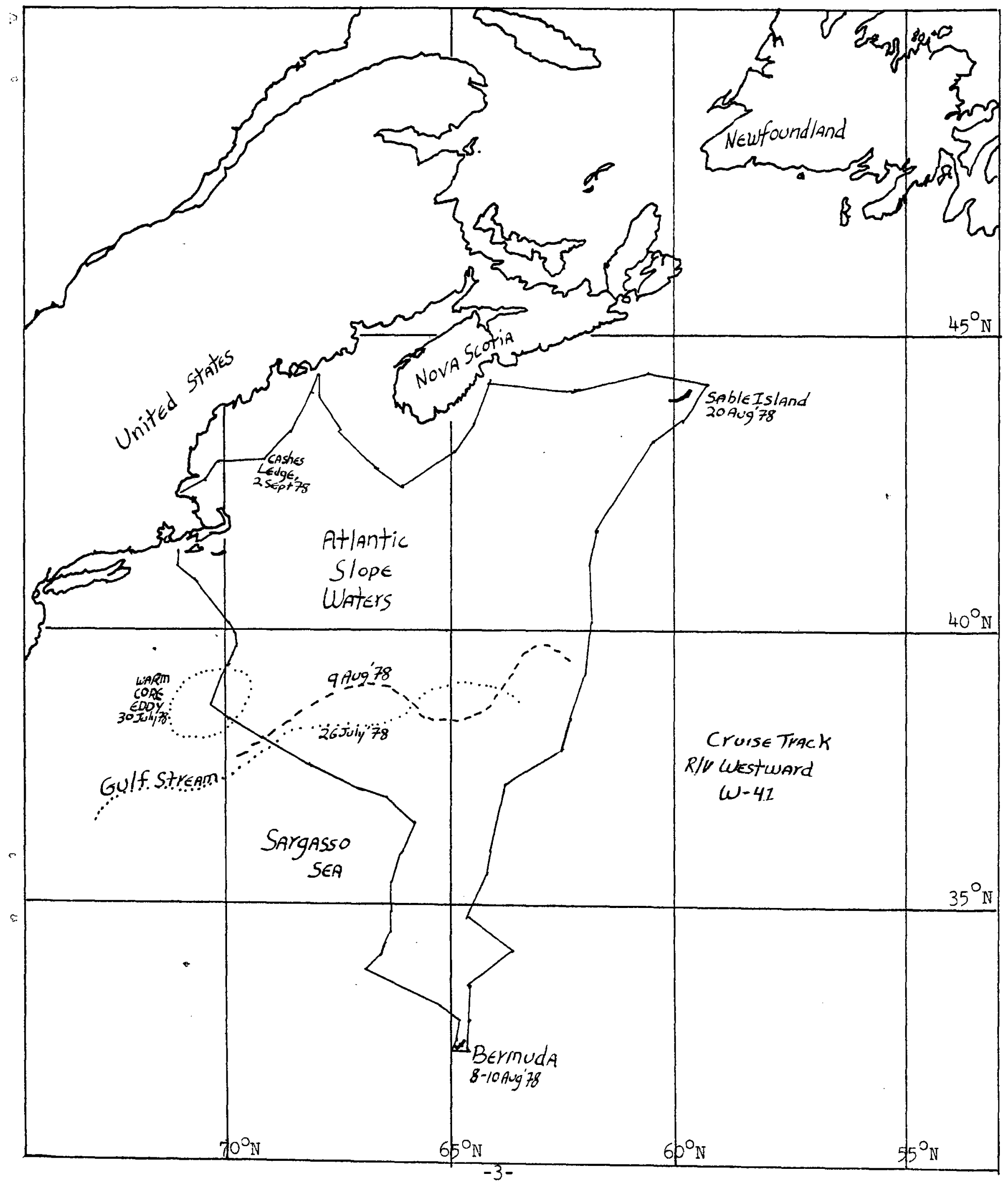




\section{W-41 Ship's Complement}

$\underline{\text { Nautical Staff }}$

Jonathan Lucas, M.M.

Richard Farrell, Licensed Ocean Operator

Captain

Richard Ogus, Licensed Mate

Ronald Harelstad, B.S.

Gregg Swanzey, B.S.

Gary Manter, Assoc. Arts

Gail Gryska, B.A.

Relief Captain

Chief Mate

$2^{\text {nd }}$ Mate

$3^{\text {rd }}$ Mate

Chief Engineer

Steward

Scientific Staff

Carl Baum, B.S.

Mary Farmer, Ph.D.

Chief Scientist

Molly Allison, M.S.

Assistant Scientist

Abigail Ames, B.S.

Assistant Scientist

Assistant Scientist

\section{Visiting Investigators}

Patricia McGill, M.S., Wildlife Science, Cornell University; (Woods HoleBermuda)

Edward Robb, D.V.M. Candidate, N.Y. State College of Veterinary Medicine at Cornell University; (Bermuda-Lunenberg, Nova Scotia)

Wm Timothy Rumage III, M.S., Biol. Science, Boston University; (Bar Harbor, Maine-Boston)

Students

William Belisle

Margaret Davis

Charles Deutsch

Bradley Gandrup

Jenny Glasser

Jeffrey Hatch

Patricia Hodges

Todd Howerton

William LaParl

Christian Letelier

Janet Llewellyn

John McAlpin

Charles Morss

Ralph Owen

Josie Quintrell

Carl Rand

Dwight Reese

Lisa Robbins

Lena Sanentz

Carolyn Steiner

Herve Thebault

Marion Valpey

Thomas Ziewacz
College

Boston University

Whitman College

Cornell University, N.Y.

Univ. of Connecticut

City College (C.U.N.Y.)

Framingham State College

Wellesley College

Goucher College

Boston University

American University

$U$. of Nebraska at Iincoln

Oberlin College

Connecticut College

$U$. of Massachusetts

Colby College

Occidental College

Boston University

Vanderbilt University

Harvard University

Oberlin College

University of Grenoble

Wellesley College

$U$. of Wisconsin 


\section{Academic Program}

The academic program on $W-41$ consisted of a series of lectures and seminars, 150 hours on watch instruction and discussions, and independent student research projects. For grading purposes, students were evaluated according to their performance in the following three areas on an equal weight basis: 1) lecture and laboratory final testing*, 2) on-watch performance as research assistants, and 3) quality of individual research project effort.

Lecture material was designed and presented to coordinate with current research activities in the laboratory. The ship's sclentific staff and visiting investigators contributed according to their own backgrounds and, during the final leg of the cruise, students delivered seminars based on their completed project work.

Three students per watch were assigned to the laboratory on a rotating 24 hour basis. Under the guidance of a member of the science staff, watch standers discussed, and received technical on-the-job training in the various sampling techniques, analyses, and data reduction processes involved in the research program. Time was also alloted to their personal project work and special interests.

Student project work commenced during the shore component in Woods Hole where they may avail themselves of the unique resources of an oceanographic community in the design of a testable project hypothesis. The continuing advice and constructive criticism of the staff aided each student in the execution of his project aboard ship. The students were nevertheless entirely responsible for the final products of their efforts, the abstracts of which appear in the following pages. The complete works are maintained on file at S.E.A.

During the course of the cruise, students were given the opportunity to visit the following places of educational interest ashore:

1) The Bermuda Biological Station, Bermuda

2) A coral reef dive, Bermuda

3) The Bermuda Marine Aquarium

4) The Lunenberg National Fisheries Museum (Currently under improvement) Lunenberg, Nova Scotia

* The laboratory final was based largely on knowledge of a biological teaching collection assembled during the cruise (see appendiy.2.) 


\section{Staff Lectures}

Research Objectives and Academic Responsibilities Baum/Farmer for $w-41$

The Bathythermograph and Ocean Thermal Structure

Ames

Nansen Bottles and Reversing Thermometers

Ames

Titration Technique

Ames

Phytoplankton and Primary Productivity

Farmer

Fish Taxonomy and General Biology

Baum

Biology of Pelagic Birds

McGill

Coral Reef Ecology

Baum/Farmer

The Sargas sum Weed Community

Allison

Zooplankton Taxonomy and Identification

Allison

Qualitative and Quantitative Analysis of a Zooplankton Tow

Mesopelagic Ecology

Baum

Identification of Great Whales and Some Common Dolphins

Allison

Fish Pathology

Robb

Long Iine Technique and Shark Dissection

Baum

Marine Bioaccoustics

Rumage

\section{Student Seminars}

Family Diversity fo Anguilliform Leptocephalus Larvae

Diversity of Macrofaunal Associates in Sargassum Weed

Hatch/Owen

Reese

LaParl

Standing Crop of Pelagic Sargassum Weed and Tarball Concentrations

Seabird Density and Diversity in Relation to Water Mass Productivity

Quintrell/steiner 
Student Seminars Cont.

Morphological Adaptations of Some Neuston Fishes Thebault

Diversity of Fish in the Neuston Layer

Ziewacz

Distribution of Genera of the Midwater Fish Family Rand Myctophidae

Vertical Migration of Mesopelagic Fishes

Sanentz

The Effect of Ecotones on Diversity, Biomass and Davis Relative Size of Zooplankters

The Relationship between Summer Distribution of Deutsch Baleen Whales and Zooplankton Abundance in Atlantic Coastal Waters

A Comparison of Temperature-Salinity Profiles from Howerton/Hodges Several Water Masses

A Comparison of Nutrient Levels in Several Water Ilewellyn/Robbins Masses

Intercalibration of a Secchi Disc and Submarine Photometer

Glasser

The Effect of Surface Water Changes on Weather

Morss

International Whaling Legislation with Special Emphasis on Canada

Letelier

The History of Whaling with a Profile of the Canadian Industry

McAlpin

Technical Photography and Shipboard Film Development Belisle

Experiments in Iife Boat Navigation Gandrup/Valpey 
Research activities conducted during $W-41$ were divided into three categories: 1) cooperative research accomplished for outside agencies, 2) in-house research originated by S.E.A. staff members, and students under staff direction, and 3) short term programs conducted by visiting investigators (see appendix 1. for a summary of stations taken). The results of each are presented below in abstract form, together with tabulated and graphic data in a preliminary state of refinement. It will be noted that an effort has been made to integrate student project work with staff research in order that each party's interests be best served.

\section{Cooperative Programs}

\section{A. Ship's Weather Observations Program (NOAA)}

When underway offshore, the $\mathrm{R} / \mathrm{V}$ Westwarc routinely gathers weather observations for the National Oceanic and Atmospheric Administration in conjunction with international weather and surfacetruth programs. Synoptic data is collected and transmitted to U.S. Coast Guard shore stations at 0600 and 1200 GMT daily.

Thirty-two sets of synoptic observations were recorded on $W-41$ and appear in Appendix 3. The rate of successful transmission was approximately 50\%. Unsuccessful attempts were accounted for by shipboard radio failures, poor transmission conditions, and unexplainedfailures to answer on the part of the Coast Guard.

\section{B. Shark Tagging by Long Line (NMFS)}

This program is conducted in cooperation with Dr. Jack Casey at the National Marine Fisheries Service, Narragansett Lab, R.I. Sharks are captured on long lines stretching one half to one mile in length and consisting of 50-100 baited hooks. Captured sharks are tagged after ascertaining identity, sex, length and unusual characteristics. This study endeavors to elaborate upon the suspected migratory habits of certain species.

Two eighty-hook longlines were set at two fathoms in the Gulf of Maine on $\mathrm{W}-41$ : one at Cashes Ledge $\left(43^{\circ} 03^{\prime} \mathrm{N}, 68^{\circ} 20^{\prime} \mathrm{W}\right)$ and a second at Stellwagon Bank $\left(42^{\circ} 3 I^{\prime} \mathrm{N}, 70^{\circ} 20^{\prime} \mathrm{W}\right)$. Frozen 12 -inch macke rel were used as bait. In all, 35 male blue sharks, Prionace glauca, ranging in overall length from three to nine feet (mean $=5.8 \mathrm{ft}$ ), were captured; 33 were tagged live and relessed. Of the two that expired, one seven foot specimen was dissected as a demonstration for students. No internal abnormalities were noted.

II. In-House Research

A. Zoogeography of the Midwater Fauna of the Western North Atlantic As a part of an ongoing study following the work of Dr. Richard 
Backus et al., of Woods Hole Oceanographic Institute, six IsaacsKidd midwater trawls were conducted along the $W-41$ cruise track in order to provide material for investigating variations in the faunal assemblages between adjacent water masses. Carl Rand examined lantern fishes of the family Myctophidae to test the Gulf Stream as a faunal boundary between North American Slope and Sargasso Waters. Margaret Davis examined the relative diversity, density, biomass and size of Midwater Zooplankton collected at the Gulf Stream edge to look for ecotone effects. As with previous cruises, the midwater fish samples will require further work ashore before results can be critically analyzed in light of Backus et alo's findings.

1) Distribution of Genera of the Family Myctophidae in Slope Water, Gulf Stream and North Sargasso Sea (Carl Rand)

Abstract

The distribution of genera of the family Myctophidae (Teleostei) was investigated to determine faunistic differences between the slope Water, Gulf Stream and North Sargasso Sea water masses. This analysis of lanternfish distribution was carried out in conjunct:on with biological and hydrological sampling aimed at characterizing the se three water masses. Results were compared to those obtained by Backus et al. specimens were collected during a series of oblique, nocturnal IsaacsKidd midwater trawls at depths ranging from 600 meters to the surface and identified at the generic level. North Sargasso Sea and Slope Water were found to be faunistically distinct environments; the Gulf Stream, which acts as a boundary between the two, contains genera common to both. Additionally, Slope Water and North Sargasso Sea share similar diversity indices ( 1.36 and 1.21 respectively) while the diversity index of the Gulf Stream is reasonably higher (2.34).

(See Table 1.)

Table 1. Distribution and biomass of myctophid genera

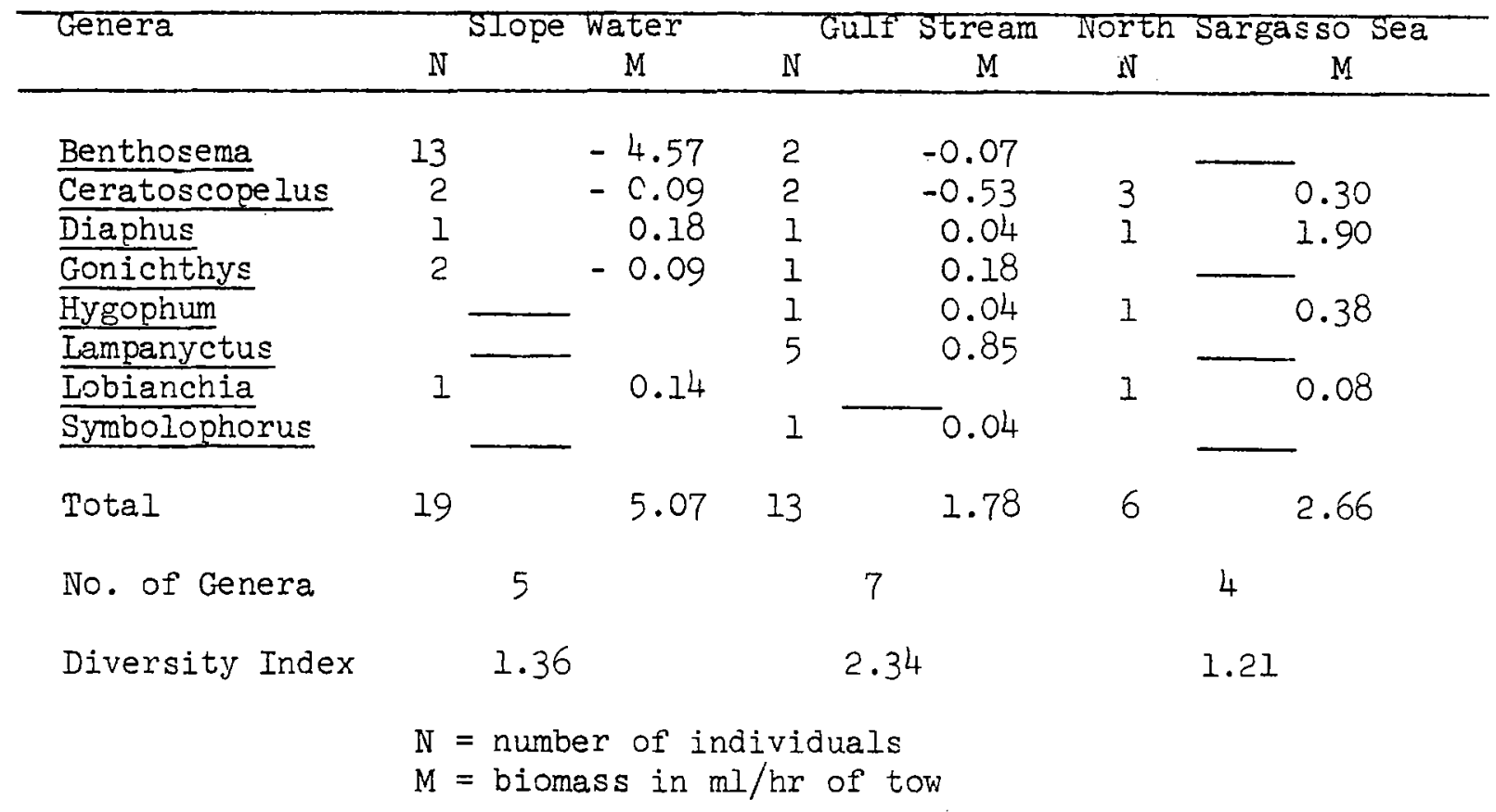


2) The Effect of Ecotones on Diversity, Biomass and Relative Size of Zooplankton in the North Atlantic (Margaret Davis)

Abstract

The convergence of distinct communities produces a transition area known as an ecotone characterized by an environment intermediate between that of each of the overlapping regions. High population density and diversity have been associated with these zones due to the presence of organisms from the bordering regions as well. as those specifically adapted to ecotones (Odum, 1953). A relative increase in size has also been noted when observing ecotonal water masses in the North Atlantic (Baum, personal communication).

Six Isaacs-Kidd midwater trawl samples were analyzed from regions bordering the Gulf Stream and within the Sargasso Sea and Slope waters. Total biomass was measured in number of animals per hour of towing time, and diversity was found using the index $D=S-I / I n N$. A random sample of euphausids was measured from each station to determine the presence of gigantism.

Relatively high diversity and population density were noted in two samples taken within or near the ecotones along the northern and southern walls of the Gulf Stream. One sample taken within the Sargasso sea yielded comparatively low biomass and diversity as well as a relatively small size of euphausids, while a sample taken from Slope waters produced opposite results, yet lower than those seen in the ecotone. The first sample, taken along the southern edge of the Gulf Stream gave poor results which may indicate an error in judging the position of the ecotone at that time. (See Table 2.)

Table 2. Edge effect reflected in biomass, number of kinds and diversity of organisms, and average size of euphausids in six IKMTS

\begin{tabular}{|c|c|c|c|c|c|c|c|}
\hline - & 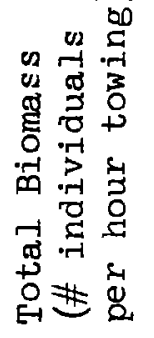 & 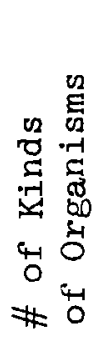 & 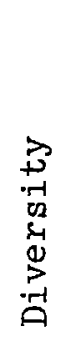 & 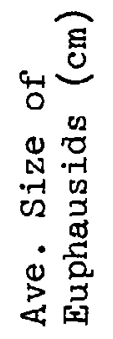 & 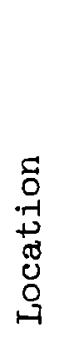 & प- & $\overbrace{0}^{Z}$ \\
\hline
\end{tabular}

$\begin{array}{rrrrr}1 & 338.00 & 9 & 0.859 & 1.220 \\ 2 & 1823.90 & 11 & 1.330 & 1.600 \\ 3 & 472.12 & 9 & 1.290 & 0.880 \\ 4 & 632.25 & 7 & 0.930 & 0.700 \\ 5 & 3710.35 & 13 & 1.460 & 1.725 \\ 6 & 1247.69 & 9 & 1.120 & 0.750\end{array}$

Gulf Stream South Edge Sargasso Sea

Bermuda Gulf Stream South Edge Gulf Stream North Edge No. American Slope Water

Total Average Size $=1.14 \mathrm{~cm}$ 
B. Diel Periodicity in the Western North Atlantic

Two diel (24 hour) stations were conducted on W-41 and modeled after those developed by Farmer and Baum (W-40 Cruise Report). Each station consisted of four sets each of the following operations spaced at six hour intervals around the clock: 1) a bathythermograph to $900 \mathrm{ft} .2$ ) a hydrocast with bottles at 0 , thermocline, 200 and 400 meters, 3) a submarine photometer (Kahl 268WA310 Irradiometer) reading to 25 meters (daylight), and 4) a concurrent multiple-net zooplankton tow sampling at thermocline, 200 and 400 meters. Vertical and temporal regimes for temperature, salinity, dissolved oxygen, phosphate and nitrate were derived for each station from the nansen bottles; coefficients of incident light extinction and compensation depths (one per cent light depth) were derived from the photometer data; and the net samples were analyzed for biomass (volume displacement) of dominant taxonomic groups of zooplankton and mesopelagic fish.

This complex station constitutes an effective tool for characterizing and comparing water masses with respect to the dynamic activity of their physical, chemical and biological properties, thus providing a broader picture than would be obtained from a single samp1ing. Of particular interest to this cruise was the quantitative picture of vertical migration in midwater fauna provided (in relation to changing and static physical and chemical parameters.) Further, the diel activity of a warm core eddy located 180 miles south of Cape Cod on $29 \mathrm{Ju} 1 \mathrm{y} 1978\left(38^{\circ} 33^{\prime} \mathrm{N}, 70^{\circ} 08^{\prime} \mathrm{W}\right)$ was compared to that of its hypothetical parent waters in the Sargasso Sea at the southern edge of the Gulf Stream 360 miles to the East (37047' N, 62035' W). Together with hydrographic data collected in the vicinity of these sites, the pair of diel stations provided a means of measuring the state of decay of the warm core eddy by degree of similarity in all respects to parent and present surrounding waters. Additional stations on subsequent cruises will further elucidate this picture.

Preliminary chemical and physical data for the diel stations can be located in The Hydrographic Data Log (Appendix 7.). Figure 2 depicts the diel vertical migration of midwater fauna in relation to changing chemical and physical factors. Lena Sanentz examined the vertical migratory behavior of three families of midwater fish. Various other aspects are dealt with in part by student reports in later sections.

1) Mesopelagic Fishes in the Western North Atlantic Vertical Migration (Lena Sanentz)

\section{$\underline{\text { Abstract }}$}

In order to measure vertical migration, two meter nets and a bongo net were used to collect samples of mesopelagic fishes from depths of 20-75,200 and 400 meters respectively, at four stations during a 24 hour period. Two water masses were sampled: a warm core eddy $\left(380^{\circ} 22^{\prime} \mathrm{N}, 70^{\circ} 08^{\prime} \mathrm{W}\right)$, and Sargasso Sea $\left(37^{\circ} 45^{\prime} \mathrm{N}, 62^{\circ} 33^{\prime} \mathrm{W}\right)$. Biomass was measured by volume displacement of fish per cubic meter water filtered in the nets. 
Figure 2. Diel activity of midwater fish and total zooplankton (blomass), 1ight intensfty, phosphate-phosphorus ( $\left.\mathrm{PO}_{4}-\mathrm{P}\right)$, and dissolved oxygen ( $\mathrm{O}_{2}$ ) in two water masses: a warm core eddy and the Sargasso Sea. Four sampling sets at even intervals ln 24 hours.

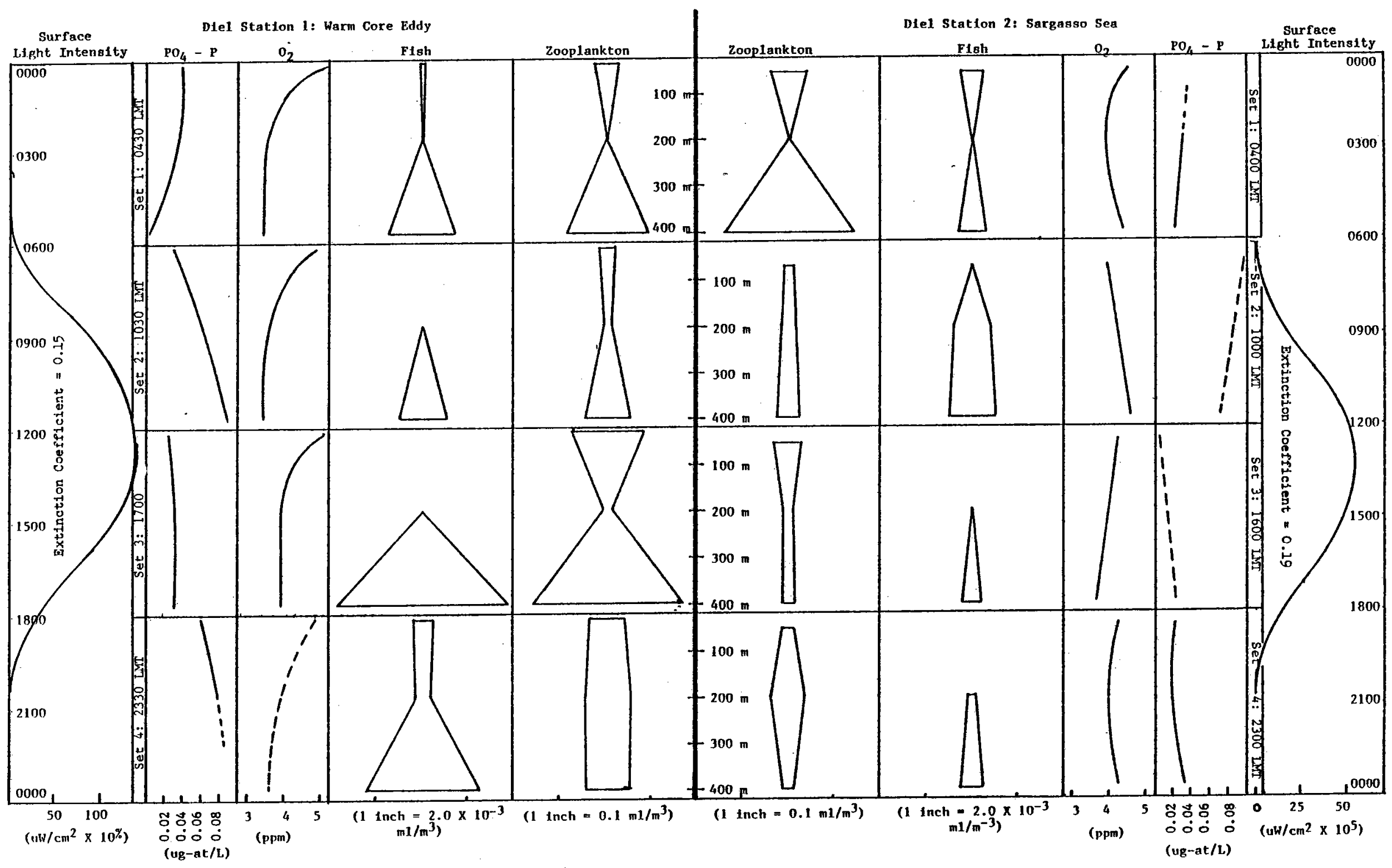


The night catches per unit volume filtered were larger than the day catches at depths of 20-75 meters, while the day catches per unit volume were larger than the night catches at depths of 200-400 meters. The daytime increase at greater depths, and the night-time increase in shallower waters was used as an estimate of vertical migration. Night-time increase in surface waters exceeded daytime increase at higher depths. Differences in vertical migratory behavior at the familial level are indicated by the dominance of Myctophids above 200 meters, and Gonostomatids below 200 meters in night tows. On a comparitive basis, the eddy fish followed the normal pattern of postsunset and predawn rises, while the Sargasso Sea fish exhibited only a prolonged morning rise. This difference could be accounted for by the overall greater standing crop of fish in the eddy waters, but remains largely unexplained for lack of sufficient data. (See Figure 2.)

\section{Distribution of Anguilliform Leptocephalus Larvae in the Western North Atlantic}

This work involved a series of five stations (see Appendix 1) each consisting of a bathythermograph, a hydrocast to 400 meters and a zcoplankton tow stepped at $100,75,50$ and 25 meters. Larvae collected in these tows and all other tows were identified and correlated with bathymetric and geographic parameters. Family diversity of leptocephalus larvae collected along the cruise track was the subject of a study by Ralph Owen and Jeff Hatch.

Particular attention was paid to larvae of the American and European freshwater eels, Anguilla sp., the object of a study initiated by Dr J.H.W. Hain, formerly of S.E.A. This species is believed to spawn in the Sargasso Sea southwest of Bermuda, with subsequent migration of the larvae back to the adult habitat in fresh water systems of coastal North America and North Europe. It is hoped that a more detailed picture of the location of the spawning area and nature of the migration in these eels will be gained from this research. Results will be made available to Dr. Hain.

1) A Study of Family Diversity in Anguilliform Leptocephalus Larvae in the Western North Atlantic (Hatch and Owen)

Abstract

Family diversity of anguilliformes leptocephali was measured along the cruise track of $W-41$. Specimens were taken using the mu1tiple net towing technique devised on $W-41$ (meter net at 26 meters; meter net at 200 meters; Bongo net at 400 meters) and from various IKMT and Neuston tows. The cruise track was divided into two communities to facilitate diversity analysis: North of the Gulf Stream and South of the Gulf Stream (including the Gulf Stream and the Sargasso Sea area). Sixty-nine specimens of anguilliform leptocephali from 10 families were taken at probable depths of 0-100 meters during the hours 2100 to 0300 . The greatest diversity was shown north of the Gulf Stream (5.41 vs. 3.26 south of Stream). The most abundant families were Muraenidae (28 individuals), Anguillidae (12), 
and Synaphobranchidae (12). Anguillidae showed an average size of $4.5 \mathrm{~cm}$ near Bermuda and up to $6.0 \mathrm{~cm}$ near Sable Island, N.S., supporting the theory that Anguilla spawn in the Sargasso Sea area. Muraenidae as well as all the other families were found above the $15^{\circ} \mathrm{C}$ isotherm and the $36 \%$ isohaline as expected. All leptocephali were found at depths above $150 \mathrm{~m}$ (estimated from towing data). (See Table 3.)

Table 3. Lengths of anguillid leptocephali reflecting increased size in higher latitudes

\begin{tabular}{lcccc}
\hline Station & Date & \#Specimen & Mean Length & Latidude \\
\hline Ee1 \#3 & $8 / 04$ & 2 & $5.2 \mathrm{~cm}$ & $34^{\circ} 09^{\circ} \mathrm{N}$ \\
Eel \#2 & $8 / 01$ & 5 & $4.5 \mathrm{~cm}$ & $36^{\circ} 56^{\prime} \mathrm{N}$ \\
IKMT 4 & $8 / 15$ & 1 & $4.7 \mathrm{~cm}$ & $38^{\circ} 18^{\prime} \mathrm{N}$ \\
Diel \#1, Set 1 & $7 / 29$ & 1 & $4.8 \mathrm{~cm}$ & $38^{\circ} 33^{\prime} \mathrm{N}$ \\
IKMT 5 & $8 / 17$ & 1 & $5.6 \mathrm{~cm}$ & $40^{\circ} 07^{\prime} \mathrm{N}$ \\
IKMT 6 & $8 / 18$ & 1 & $6.0 \mathrm{~cm}$ & $42^{\circ} 59^{\prime} \mathrm{N}$ \\
\hline
\end{tabular}

D. The Distribution and Acoustics of Marine Mammals in the Western North Atlantic

As a part of a continuing program, all marine mammal sightings were recorded along with pertinent behavioral and geographic data (see Appendix 4). In addition, an intensive whale watch with two lookouts aloft waskept during daylight hours on Leg III, while transiting known summer feeding grounds of great whales in the Scotian and New England coastal waters. Most notable was the sighting of a pod of Sperm whales, of mixed ages, numbering no less than 15 individuals, just south of the Gulf Stream main axis.

Eight acoustic stations were conducted with a recording hydrophone in association with major sightings or suspected presences (see Appendix 1). The only vocalizations detected and recorded came from the above mentioned sperm whales. The combined sighting and acoustic data will be made available to interested parties: notably $\mathrm{Dr}$. H. Winn of the University of Rhode Island, Dr. Steven Katona and Mr. Scott Kraus of the College of the Atlantic, and Dr. J.H.W. Hain,

Charles Deutsch investigated the relationship between whale populations and zooplankton abundance. Bill Belisle documented sightings photographically and devised a process for the color slide film development aboard ship. John McAlpin and Chris Latelier researched the related topics of whaling industry history and legislation.

1) The Relationship Between Summer Distribution of Baleen Whales and Zooplankton Abundance in the Waters off Nova Scotia and in the Gulf of Maine (Deutsch)

Abstract

Zooplankton is the primary food source for most species of baleen 
Table 4

The Relationship between the Local Summer Distribution of Baleen Whales and Zooplankton Abundance in the Waters off Nova Scotia and in the Gulf of Maine

Plankton Tow \#

per Whale Census 1
2 3

4

5

6

7

8

\begin{tabular}{|c|c|c|c|c|c|c|c|c|c|}
\hline $\begin{array}{l}\text { WATER } \\
\text { MASS }\end{array}$ & $\begin{array}{l}\text { Continental } \\
\text { Slope Break }\end{array}$ & $\begin{array}{l}\text { Scotian } \\
\text { Shelf Break }\end{array}$ & $\begin{array}{l}\text { Gully } \\
\text { Sable }\end{array}$ & $\begin{array}{l}\text { off } \\
\text { Is. N.S. }\end{array}$ & $\begin{array}{l}\text { Coastal } \\
\text { (St. Margaret's } \\
\text { Bay, N.S.) }\end{array}$ & $\begin{array}{l}\text { Baccaro } \\
\text { Bank }\end{array}$ & $\begin{array}{l}100 \text { fathom } \\
\text { curve } \\
\text { West of } \\
\text { Brown's Ban }\end{array}$ & $\begin{array}{l}\text { Casher } \\
\text { Ledge }\end{array}$ & $\begin{array}{l}\text { Stellwagen } \\
\text { Bank }\end{array}$ \\
\hline
\end{tabular}

Census Period Index

34.0

49.0

31.7

32.6

38.1

49.0

$37 \cdot 9$

PLANKTON

$\left(\mathrm{ml} / \mathrm{m}^{3} \times 10^{-3}\right)$

9.25

3.5

38.3

219

524

53.6

138

271

Major

Diverse: Euphausiids Copepods

Organisms Euphausiids, Chaetognaths

Copepods, some Ctenophores \& Chaetognaths

Copepods Ctenophores Copepods Copepods (Ctenophores, (Jellyfish, Amphipods) Euphausiids)

\section{\# Baleen whales \\ observed during \\ Census}

0

0

0

15-19

1

1

Ctenophores

0

Depth (M)

2500

240

410

50

100

200

150

84

Surface Temp.

$23 \cdot 3$

20.0

19.5

16.1

14.2

15.8

19.7

18.1

Beaufort Force of Wind

4

3

4

$3 \cdot 3$

2

1

0

4 
whales during the summer feeding season. The relationship between the local distribution of mysticete whales and the abundance of zooplankton was studied on the continental shelf off Nova Scotia and in the Gulf of Maine. Simultaneous plankton tows and ten-mile long whale censuses were taken at eight locations along the cruise track. Zooplankton biomass was determined by the volume displacement technique, and it was used as an index of the relative productivity of the water mass. No whales were observed in the low productivity localities, whereas large aggregations of these animals--including seis, fins, and humpbacks--were found in the two areas which had the greatest zooplankton biomass. The plankton samples from the productive waters were composed primarily of copepods. The populations of baleen whales seemed to be locally distributed over the highly productive offshore banks. (See Table 4.)

2) Photographic Identification of Individual Humpback Whales in the Western North Atlantic (Belisle)

\section{Abstract}

Photographs of marine biota found along the cruise track of Westward, $W-41$, were taken using $35 \mathrm{~mm}$ still camera and various wideangle, close-up, and telephoto lenses.

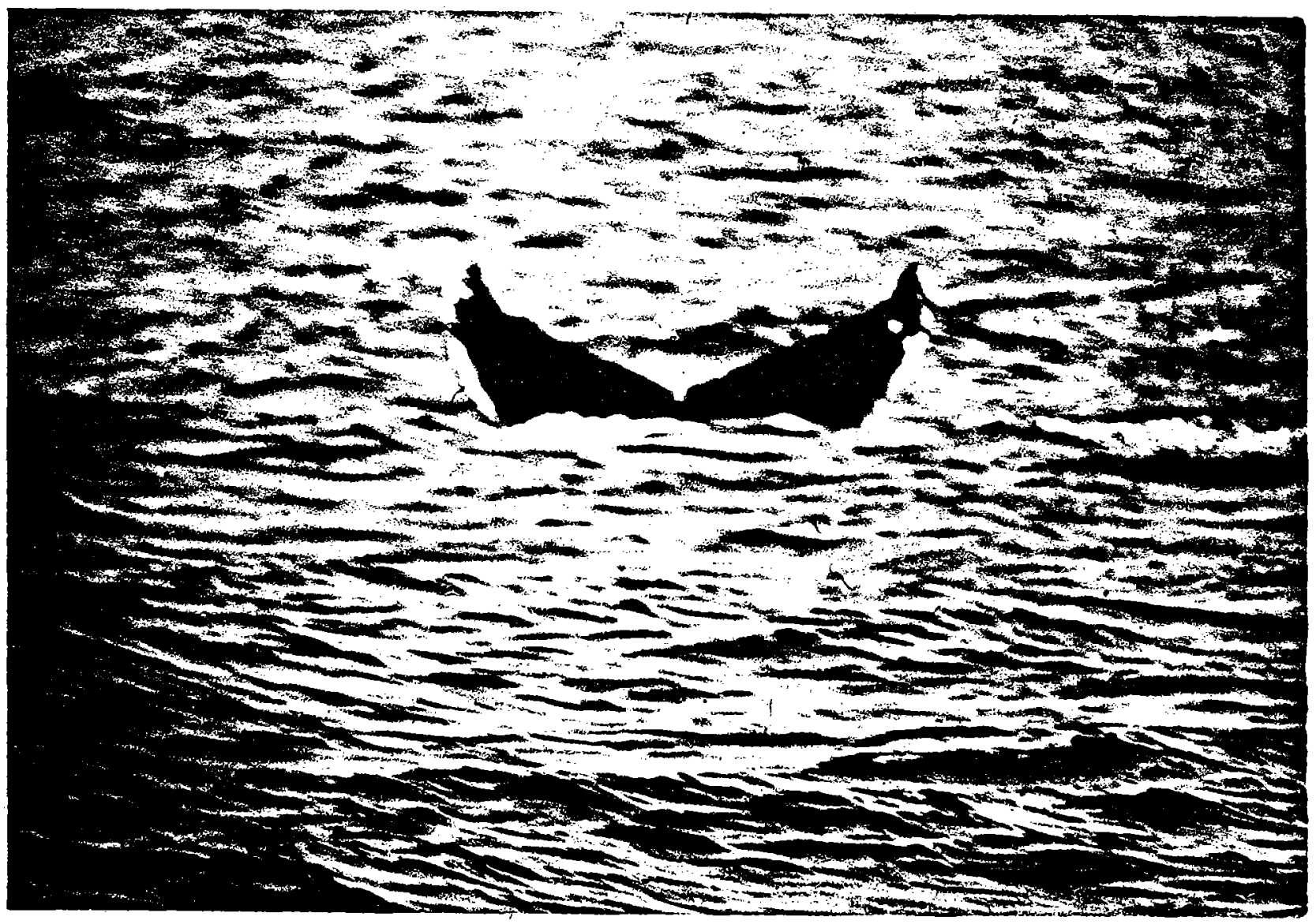

Plate 1. Humpback whale sighted 3 September 1978, on Stellwagon Bank 
Immediate access to photographs was provided by an on-board color slide developing station which yielded results comparable to commercial quality development techniques. Standard Kodak chemicals were used to develop Ektachrome slides in E-6 chemistry.

An attempt to identify individual whales by tail fluke markings met with partial success by yielding a photograph of a humpback whale which may have been previously identified. Tail fluke markings in humpbacks are distinctive enough to identify individuals of the species, and are compiled in a photographic guide, (Katona et al, 1977). This information will be sent to Dr. Katona at the College of the Atlantic. (See Plate 1.)

3) The History of Whaling with a Profile of the Canadian Industry (McAlpin)

\section{Abstract}

The overexploitation of the world's wild stocks of animals can be exemplified by a description of man's mismanagement of the whaling industry. Beyond the leviathan's awesome totality, it has no natural enemies in its environment except man, who has taken to the seas with such vigor that the whale stocks are in serious decline.

For centuries the whale has captured the imagination of men, and has become an intricate part of their superstitions, mythology, and folklore, though until recently mans efforts at capturing whales have been far removed from scientific-factual knowledge of its life history and behavior.

The whaling industry has experienced many changes since its inception in the 11-12th century with the Basques, who set a precedent for the history of whaling--the total decimation of an entire local population with the subsequent migration of the whalemen to new slaughtering grounds.

The Dutch-dominated arctic whaling of the 17-18th century was eventually abandoned because of the scarcity of whales. The pelagic efforts of New Englanders seeking the riches of the sperm whale flour ished, until a chain of events, including the discovery of crude petroleum and the Civil War, crumbled that industry into an irrepairable state.

The modern age of whaling is characterived by many new inventions and has evulved into a computerized, technologically dependent industry. The awesome efficiency of the giant factory ships and their associated killer ships have revolutionized the industry and if whaling were allowed to continue unchecked, would inevitably spell catastrophe for the already depleted stocks of many species.

Iñternational legislation is currently negotiating reasonable quotas and maximum sustainable yields of the wild stocks, in an effort to rejuvinate or at least prolong, an industry that has pursued a pattern of exploitation while ignoring scientific knowledge of the whale. 
Historically, the Canadian industry was a shore-based enterprise, though at its inception the pelagic trend of the 18th century was carried on by a band of Nantucket whalemen imported to Dartmouth, Nova Scotia. Modern Canadian whaling ended in 1972 on a controversial note, as the men who lost their jobs were outraged as they felt the closing of their station at Blandford, Nova Scotia was for purely political-public sentiment reasons, rather than a necessity in closing because of any real threat to the population stocks of whales.

4) International Whaling Legislation from 1908 to 1978; with Special Emphasis on Canada (Letelier)

Abstract

Legislation pertaining to whales was traced in the international sphere from 1908 until the present in part $I$, while Canadian legislation was dealt with more on a contemporary basis from about 1969 until the present in part II.

In the case of International whaling, early attempts at legislation were discussed and finally special emphasis was given to the International Whaling Commission, IU.C., beginning in 1946. Topics that were dealt with included: the modern factory ship, Paul Savagin's warning in 1910, countries which initially joined the I.W.C. as well as those that never did, problems with the implementation of I.W.C. policy including the tragedy of the blue whale unit (B.W.U.), Japanese and Soviet public boycotts, the gestation period of whales, the U.S. proposal for a ten year moratorium on commercial whaling and the current Endangered Species Act under which all whale product imports have been banned, the accepted Australian proposal which replaced the blue whale unit as a management scheme dividing all stocks of whales into one of three categories in an effort to insure the most rapid possible restoration of depleted stocks, and finally some mention of the increasing grey whale stock.

In regard to Canadian whaling legislation, three Canadian whaling reports to the I.W.C. were investigated. These were the $23 \mathrm{rd}$ (1969-1971), 24th (1973) and 27th (1975-1976) reports to the Commission. Attention was given to the Canadian Arctic Eskimo and his bowhead hunt, scientific work carried on by Canada, Fisheries Minister Davis's Communique on Canada's ban on commercial whaling, mention of a new Canadian Committee on Whales and Whaling and of the Canadian harp seal, and finally a Canadian policies trend analysis.

\section{E. Investigations into the Neuston and Sargassum Communities}

A subject of ongoing interest aboard Westward has been the neuston organisms and their relationship to the surface layer in which they dwell. On this cruise, Tom Ziewacz examined variations in neuston fish diversity between day and night, and between adjacent water masses; Herve Thebault sought to identify morphological adaptations unique to the neuston environment. The standard neuston net $(1.0 \times 0.5 \mathrm{M})$ was modified with a stabilizer plane and weighted bridle in order to increase effective towing speed from two to five knots and thus improve catch rates. 
A related subject of continuing study aboard Westward has been the ecology of the pelagic Sargassum weed entrained within the North Atlantic gyre (Sargasso Sea) and the organisms that associate with it. This unique association resembles a comparable benthic community and is thought to have evolved from the displacement of ancestral organisms with the weed fragments that drifted from an original shore environment and subsequently established a pelagic existence.

On this cruise Bill LaParl undertook a determination of the standing crop of Sargassum weed as well as pelagic tar ball concentrations utilizing neuston tow samples; Dwight Reese examined the relationship between weed mass and age, and the diversity and density of macrofaunal associates using dip net samples. Also reported below are the abstracted collective results of observations made on the biology and behavior of the Sargassum fish, Histrio histrio. Two separate mating pairs, in addition to numerous single specimens, were captured by dip net and maintained successfully in the ship's aquariums during $W-37,40$ and 41 . The interactions between these fish, the weed and its other associated fauna not only afforded a unique teaching aid in fish biology, but also provided considerable insight into the trophic relationships within the Sargassum community, which is the ultimate focus of these studies.

On completion of $W-41$, a mating pair of Sargassum fish, each measuring approximately $12 \mathrm{~cm}$, were presented to the Boston Aquarium for display and study at that facility.

\section{1) Biomass+Diversity of Fish in the Neuston Layer (Ziewacz)}

\section{Abstract}

Diversity and biomass of $\mathrm{fish}$ in the neuston layer were measured during a transect from Woods Hole to Bermuda and Bermuda to Nova Scotia. A total of twenty hour-long tows with a net $0.5 \times 1.0$ meters were done during the cruise. Species were identified or given an arbitrary designation to facilitate the calculation of diversity. Diversity was calculated using $d=s-1 / \operatorname{lnN}$, where $S$ is the number of species per tow and $\mathrm{N}$ the number of individuals per tow. Biomass in $\mathrm{ml} / \mathrm{m}^{2}$ was also calculated for each tow. Diversity was the highest (3.40), while biomass was the lowest $\left(0.4 \times 10^{-3}\right)$, per tow near Bermuda-the result of the presence of large numbers of juveniles. Biomass was highest (8.0) while diversity was low (0.57) in the Warm Core Eddy and Slope Water because of an increase in the number of a few types of individuals taken in these more fertile water masses. Night-time catches generally had a greater biomass and diversity than comparable day-time catches, due to the arrival of vertical migrators at the surface. The boundaries between adjacent water masses also exhibited relative increases in biomass and diversity. (See Table 5.) 
Table 5. Neuston tow collections: number of individuals and species, diversity, biomass $\left(\mathrm{ml} / \mathrm{m}^{2}\right)$, size ranges, and color patterns of fishes; Sargassum weed and tar concentrations.

\begin{tabular}{|c|c|c|c|c|c|c|c|c|c|c|c|}
\hline \# & $\begin{array}{l}0 \\
0 \\
+1 \\
+ \\
0 \\
0 \\
0 \\
0\end{array}$ & $\underset{E}{\stackrel{\Xi}{E}}$ & 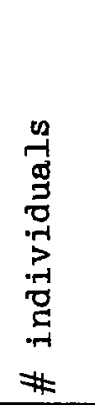 & 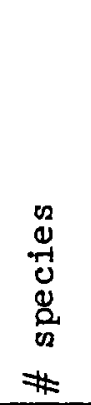 & 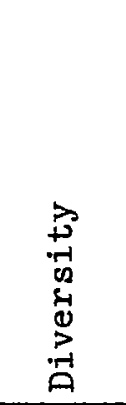 & 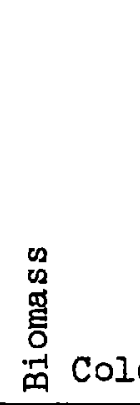 & 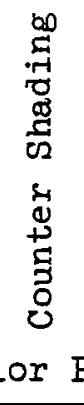 & 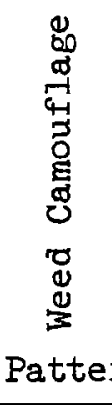 & rns & 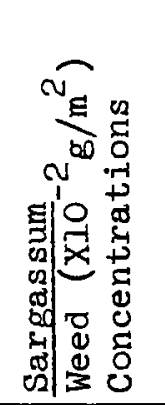 & 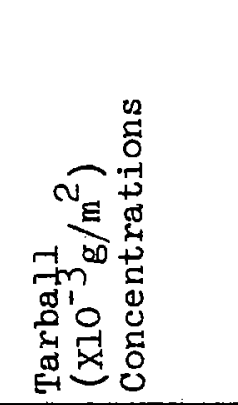 \\
\hline 1 & $\begin{array}{l}\text { warm core } \\
\text { eddy }\end{array}$ & 2130 & 35 & 3 & 0.57 & 8.0 & 34 & 1 & - & 1.433 & - \\
\hline 2 & Gulf stream & 1730 & 12 & 9 & 3.23 & 0.5 & 3 & 5 & 4 & 1.538 & 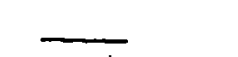 \\
\hline 3 & GuIf Stream & 1430 & 8 & 5 & 1.92 & 0.8 & 5 & 1 & 3 & 4.964 & 12.140 \\
\hline 4 & Sargasso & 0500 & 21 & 9 & 2.63 & 2.2 & 18 & $\overline{3}$ & - & 1.096 & 5.397 \\
\hline 5 & Sea & 0030 & 46 & 5 & 1.04 & 2.7 & 30 & I & 2 & 2.382 & $<1.140$ \\
\hline 6 & & 1830 & 7 & 4 & 1.54 & 0.5 & 4 & 2 & 1 & 4.984 & 9.251 \\
\hline 7 & & 1330 & 8 & 5 & 1.92 & 0.4 & 4 & 2 & 2 & 6.122 & 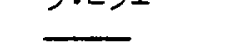 \\
\hline 8 & $\downarrow$ & 2300 & 118 & 10 & 1.89 & 3.1 & 84 & 8 & 26 & 4.047 & 4.945 \\
\hline 9 & Bermuda & 1930 & 23 & 8 & 2.23 & 0.5 & 19 & 2 & 2 & 1.527 & $<1.340$ \\
\hline 10 & & 0800 & 500 & 7 & 0.97 & -1 & 493 & 4 & 3 & 3.221 & 19.550 \\
\hline 11 & & 1400 & 115 & 6 & 1.05 & 0.5 & 112 & 2 & 1 & 3.022 & 4.430 \\
\hline 12 & & 1930 & 19 & 11 & 3.40 & 0.4 & 9 & 4 & 6 & 21.240 & 4.857 \\
\hline 13 & & 0200 & 69 & 13 & 2.84 & 0.9 & 31 & 19 & 19 & 0.222 & 3.444 \\
\hline 14 & Sargasso & 1400 & 19 & 8 & 2.38 & 0.5 & 18 & 1 & - & 12.450 & 1.904 \\
\hline 15 & Sea & 2200 & 57 & 10 & 2.23 & 2.4 & 36 & 6 & 15 & 5.963 & 5.189 \\
\hline 16 & & 2130 & 31 & 6 & 1.46 & 1.1 & 21 & 3 & 7 & 2.391 & 3.103 \\
\hline 17 & Gulf Stream & 1500 & 19 & 6 & 1.70 & 3.1 & 1 & -15 & 4 & 5.818 & $<0.498$ \\
\hline 18 & Slope & 0230 & 80 & 7 & 1.37 & 2.9 & 30 & 38 & 12 & 9.594 & 1.686 \\
\hline 19 & & 1430 & 0 & $i$ & - & 0.5 & - & 3 & - & - & 1.559 \\
\hline 20 & & 2100 & 45 & 4 & 0.79 & 1.9 & 41 & - & 4 & $\longrightarrow$ & - \\
\hline & $\begin{array}{l}\text { of to } \\
15- \\
35-\end{array}$ & $\begin{array}{l}\text { al fi } \\
9 \mathrm{~mm}- \\
4 \mathrm{~mm}-\end{array}$ & in & 0 & as & $\begin{array}{l}\text { ize } r \\
6 \% \text {, } \\
8 \% \text {. }\end{array}$ & $\begin{array}{l}\text { hges } \\
5-29 n\end{array}$ & : & $\frac{9 \mathrm{~mm}}{6 \%}$ & $\begin{array}{l}-6 \%, 1 \\
30-34 m\end{array}$ & $\begin{array}{l}-14 \mathrm{~mm}-27 \% \\
-6 \%\end{array}$ \\
\hline
\end{tabular}

2) Aspects of the Biology of Some Neuston Fishes of the Western North Atlantic--Morphological Adaptations (Thébault)

Abstract

The neuston layer of the ocean $(0-50 \mathrm{~cm})$ contains a unique biotope with specific conditions involving high solar radiations, diurnal: changes in sea temperature, high oxygen and low nutrient levels. The neuston fishes should present morphological adaptations to this habitat at a statistical level. In this study the colour and size (measured by the total length) were observed. For colour, three patterns were expected according to the idea of possible camoflage adaptations: countershading pattern (blue or green on top, silver on sides and below), Sargassum weed-1ike (white, yellow, and 
brown mottled), and any other colour (with no evidence of colour adaptations to the neuston layer). For size, the hypothetical expectation was that nanism (unusually short length) would be observed in the neuston fauna (Hartman, Jurger 1970).

Twenty tows, equally distributed through the 24-hour cycle, (for a total time of 17 hours and 30 minutes, covering a surface area filtered of $15 \mathrm{ha}$ )were taken along Legs I and II. 1223 specimens were caught. Among them $81 \%$ exhibited the counter-shading pattern and $9 \%$ the Sargassum weed camouflage. The other $10 \%$ contained juveniles whose pigmentation process had just started, and tropical reef fishes which keep the colour adaptation specific to that habitat.

For the size range, $62 \%$ of the fishes were found: in the class 10-20 mm and $91.5 \%$ between 5 and $45 \mathrm{~mm}$.

Most of the specimens observed showed colour adaptations appropriate to the neuston environment. Concerning the size range, the judgement is rather intuitive because the limits of nanism are poorly defined without any element of comparison. The observed lengths, however, appeared to be smaller than the average for the families concerned as listed in the literature. Some distortion may occur with the catch of numerous juveniles of very small size, which alters the relative abundance in these size classes, especially by day and around the island of Bermuda. (See Table 5)

\section{3) The Standing Crop of Pelagic Sargassum Weed (LaPar1}

\section{Abstract}

The standing crop of pelagic Sargassum weed for the western North Atlantic along the W4I cruise track was determined to find if the average standing crop is relatively constant. A 1 X 0.5 meter neuston net was used to perform twenty surface tows averaging one hour each. The Sargassum weed was weighed wet and in most cases the associated tar balls were collected and weighed.

Based on results from data collected on previous Westward cruises the expected average standing crop was $7.02 \times 10^{-2} \mathrm{~g} / \mathrm{m}^{2}$. Results yielded an average standing crop of $7.789 \times 10^{-2} \mathrm{~g} / \mathrm{m}^{2}$, and an average tar ball distribution of $5.027 \times 10^{-3} \mathrm{~g} / \mathrm{m}^{2}$. The average standing crop of pelagic Sargassum is therefore suggested to be relatively constant. There was no basis for comparison of the tar ball data on board for this area. (See Table 5)

4) Diversity of Macrofauna Associated with Pelagic Sargassum

\section{Abstract}

(Reese)

Sargassum weed was collected by dipnet from ten sites in the 
Sargasso Sea and the Gulf Stream on a transect from Cape Cod to Bermuda and thence to Nova Scotia. The macrofauna were collected from the weed. The ten samples contained forteen species and seventy five individuals. Diversity of species was calculated using the index $D=(S-1) /(\ln N)$. Diversity varied geographically; there appeared to be an area of low diversity in the Sargasso Sea, with high diversity occuring north in the Gulf Stream and south near Bermuda. There was a rough relationship observed between diversity and the age of weed, as measured by the amount of encrustation . This relationship was directly proportional at lower encrustation levels, and became inversely proportional at encrustation levels higher than $50 \%$. No correlation was found between surface temperature or biomass of the weed samples and macrofaunal diversity. There was no correlation between the number of individuals and the biomass of the weed. (See Figure 3)

Figure 3. Rough relatiinship between diversity of macrofaunal Sargassum associates, and per cent encrustation of weed and latitude



Abstract

Eighteen Sargassum fish, Histrio histrio, ranging 1 to $12 \mathrm{~cm}$ in approximate length, were captured in association with Sargassum weed samples dip netted from the Sargasso and Caribbean seas during cruises $W 37,40$ and 41 . Highlights of subsequent study of their 
biology in shipboard aquariums are as follows:

a) Two specimens measuring approximately $12 \mathrm{~cm}$ in standard length were captured in one $60 \mathrm{gm}$ clump of weed and later proved to be a mating pair. The fact that the female was not ready to spawn (marked by distension of the abdomen) at the time of capture, in addition to their continued coexistence (over two months) in a five gallon aquarium, indicated the possibility of long term pairing of mates without the deterance of cannibalism or individual territorial defense generally associated with this species.

b) A total of 16 spawnings between two mating pairs were partially or completely observed. Time intervals between spawning ranged from three to 15 days and appeared to be inversely proportional to food availability. The spawn is delivered in the form of a gelatinous, scrolled sheath or raft after a brief convulsive motion oriented at the surface. This is followed immediately by dispersal of the sperm arourit the raft by the male. Total eggs per raft were estimated at between 3.2 and $4.0 \times 10^{6}$, with a mean egg size of $0.5 \mathrm{~mm}$. Spawning related behavior commenced approximately 24 hours prior to actual fertilization of the eggs, and culminated consistently at 1700 - 1900 local time. Elements of apparent courtship involved close attention and physical contact paid by the male to the female for the duration of the 24 hour period, but no elaborate display language or other ritualized behavior were observed.

c) Female specimens were markedly more aggressive in feeding than males, presumably to support the metabolic demands of egg production.

d) Observed prey capture strategies were energy conservative, utilizing surprise from cemouflaged concealment and short stalking sorties in lieu of extended search and chase activity.

e) Sexual dimorphism has been tentatively established based on external features of coloration (white dotted ocelli on the lateral surfaces of the male; none such on the female), relative dorsal spine length, and ventral tassel size. Dissection of one male specimen has provisionally confirmed this

f) Two specimens became conditioned to associate approach of an aquarium net with feeding in three trials within less than 24 hours.

g) Six parasitic copepods, penella exocoeti, were removed from their attachments on the external body surfaces of one of the mating pairs. This resulted in inflamed lesions which healed within approximately one month.

h) Specimens over approximately $4 \mathrm{~cm}$ in length exhibited a transition in preference from keeping station in aquarium weed clumps to residing on or near the aquarium bottom.

i) Food items readily consumed included juvenile jacks (Caranx), Sargassum pipe and file fish species, Sargassum crustations (small shrimps and crabs), and their own kind. 
F. Island Mass Effects on Phytoplankton Communities (Farmer)

Phytoplankton populations in tropical waters are generally sparce, due primarilly to low nutrient concentrations. Tropical islands, however, may be a source of nutrients, and thus enhance the growth of phytoplankton in surrounding waters. On $\mathrm{W} 41$, ten phytoplankton tows were taken with a 0.25 meter, 60-micron mesh net on a transect approaching and circumnavigating the island of Bermuda. Samples will be thoroughly examined ashore for correlation between phytoplankton biomass and distance from land based on the above premise. Preliminary analysis by students aboard ship did not reveal the expected relationship. Dinoflagellates of the genus Ceratium were dominant in most samples. Microzooplanlton appeared more numerous than phytoplankton in every sample. It is probable that nannoplankton too small to be collected in this net account for the most numerous phytoplankton in these waters. Further studies with whole water samples will be done to ascertain what if any role oceanic nannoplankton play in island mass effects on phytoplankton populations.

G. Physical and Chemical Comparisons of Water Masses

The Westward transited five distinct water masses in the course of W 41: North American coastal andslope waters, a warm core eddy, the Gulf Stream, and the Sargasso Sea. The combined sum of hydrographic data collected in them provided several students with the opportunity to make comparative studies of vertical and horizontal profiles of physical and chemical characteristics, as well as other physical effects. Todd Howerton and Patricia Hodges examined temperature and salinity profiles; similarly, Janet Llewellyn and Lisa Robbins looked at nutrients. Jenny Glasser made a first attempt at intercalibrating a secchi disc and a submarine photometer. The effects of surficial thermal fronts in water masses on weather was the subject of Charles Morss' project. Bathythermograph profiles of the epipelagic zone for transects of the warm core eddy and the Gulf Stream are presented in Figure 4.

1) A Comparison of Temperature-Salinity Profiles of New England Atlantic and Scotian Slope, Warm Core Eddy, and Sargasso Sea Waters Abstract (Howerton and Hodges)

Water masses encountered on $\mathrm{W} 41$ were compared using temperaturesalinity diagrams and temperature-salinity vs depth curves. In particular, New England Atlantic slope and shelf, warm core eddy and Sargasso Sea, and warm core eddy and slope waters were contrasted.

Nansen bottles and reversing thermometers were used to obtain water samples and temperatures at target depths of 0 , thermocline, 100,200 , and 400 meters. Computations of actual depths of sampling based on unprotected thermometer readings proved unreliable. Therefore, depth values are based on wire angle calculations. Salinity 
Figure 4. Bathythermograph proftles of warm core eddy and Gulf stream (N-S) transects conducted on $W 41$

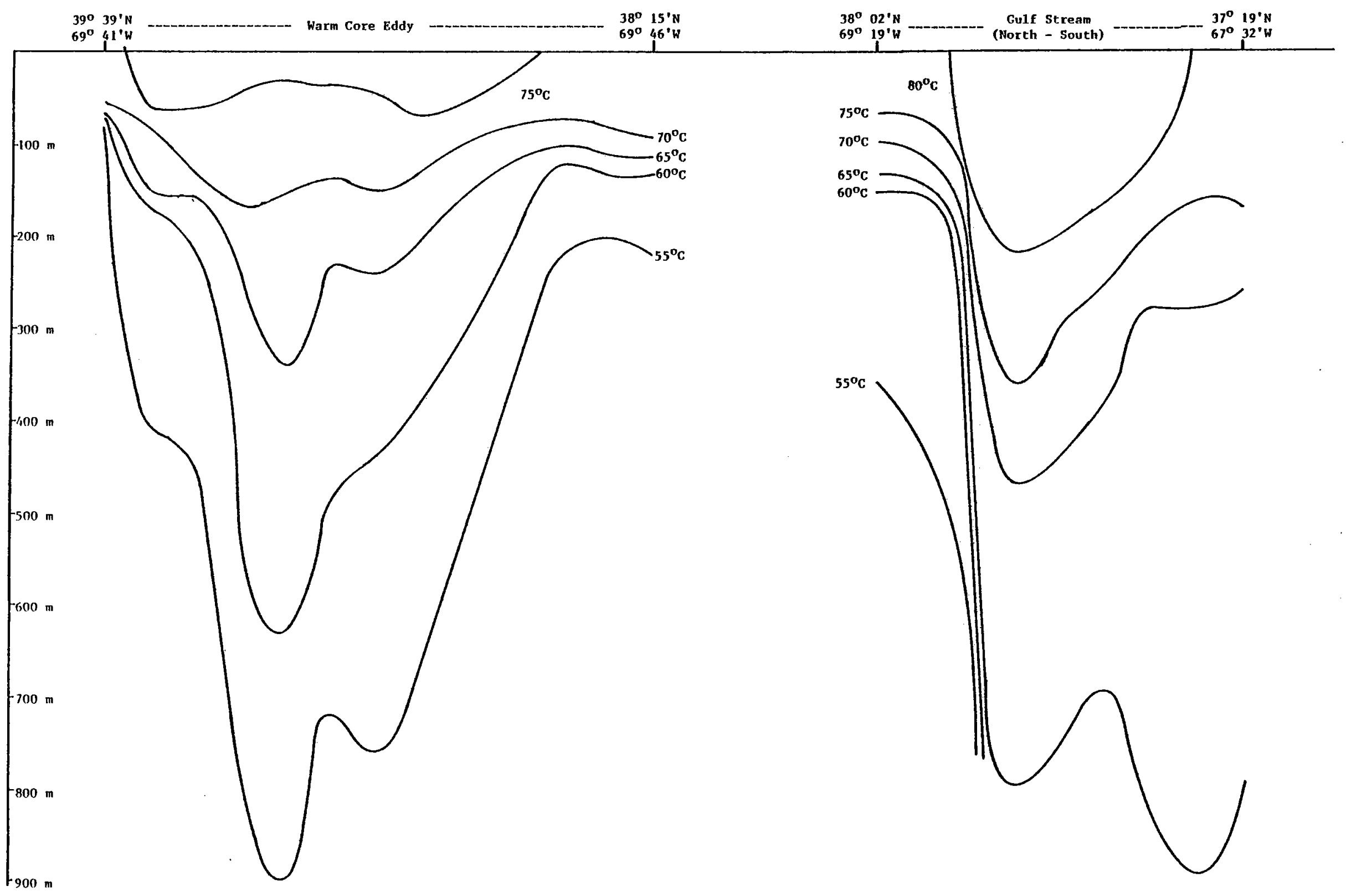


was determined by silver nitrate titration.

Results supported expectations in the warm core eddy comparisons; the eddy bore most resemblance to the Scotian slope water into which it originated, and showed remnant characteristics of Sargasso Sea water. Results from the remaining hydrocasts were somewhat inconclusive. New England Atlantic slope water was colder and less saline than the Scotian slope. This was unexpected, yet explained by the influence of the Gulf Stream which moves north during late summer. New England Atlantic shelf water was less saline: than neighboring slope water and had a more uniform temperature profile, due to river runoff and vertical mixing, respectively. (See Figure 5)

Figure 5 Exemplary temperature - salinity diagrams for U.S. slope water (2), a warm core eddy (4), the Sargasso Sea (13), and Scotian slope water (14) Salinity $(\%)$

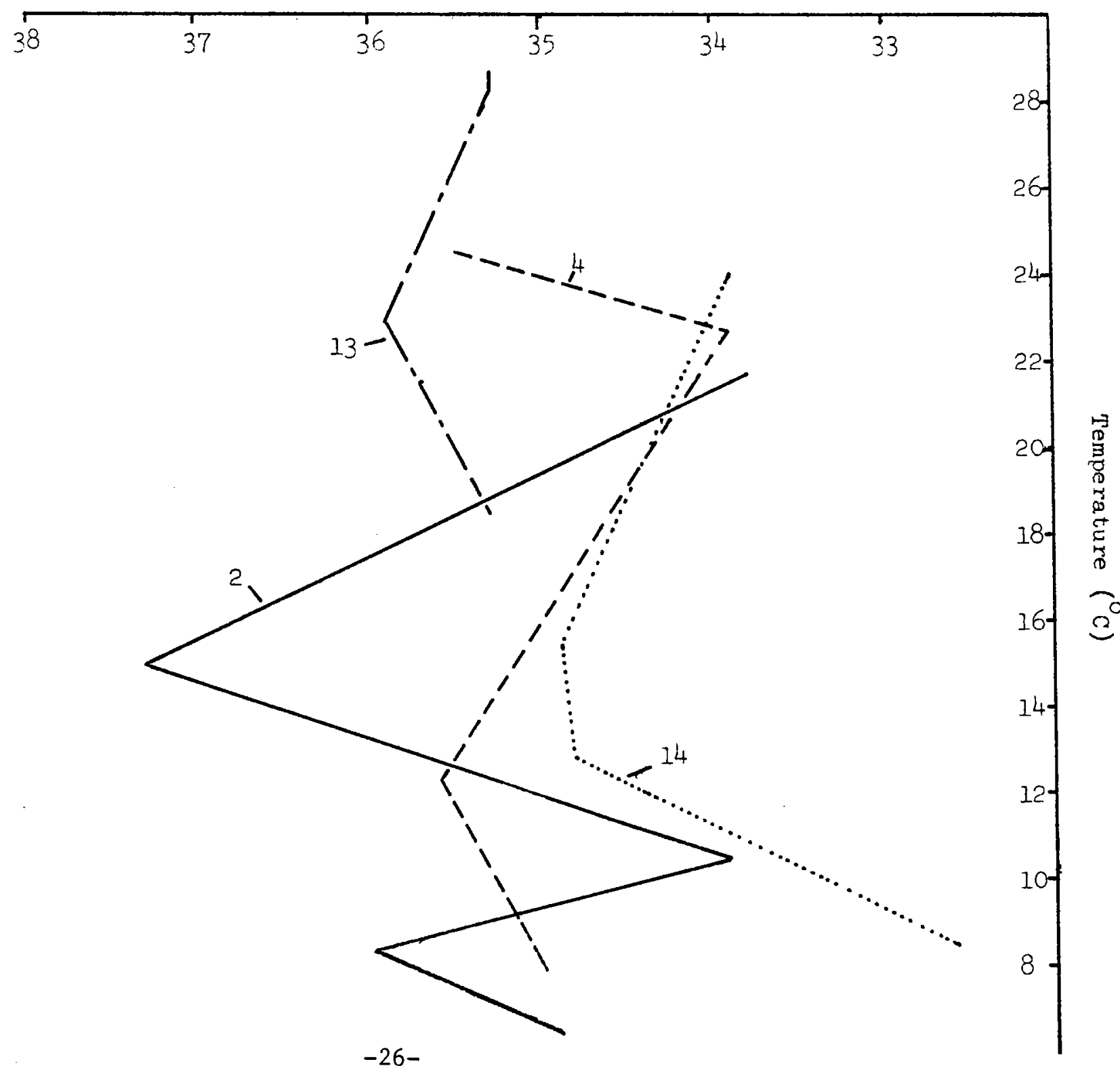


2) Nutrient Levels on the Atlantic Shelf and Slope, a Warm Core Eddy, the Sargasso Sea, and the Scotian Shelf (Llewellyn and Robbins)

Abstract

Water samples were collected from forteen hydrocast stations on the Atlantic shelf, slope, a warm core eddy, the Sargasso Sea, and Scotian slope along a transect from Woods Hole, Massachusetts, to Bermuda, and from Bermuda to Lunenberg, Nova Scotia. Each station consisted of an average of four nansen bottles sampled to a maximum depth of 400 meters. Water samples were analyzed for phosphate, nitrate and oxygen concentrations using Hach Kits (Kit NI 14 for nitrates and kit PO 19 for phosphates were under evaluation for use aboard Westward) and the Winkler method.

Theoretically, collection of data in the summer months shows low nutrient levels in the surface waters due to depletion by the spring phytoplankton bloom. These layers remain depleted throughout the summer due to lack of substantial vertical mixing. The Sargasso Sea was expected to show lower nutrient levels than the shelf and slope waters. In addition, inverse correlations between oxygen and nutrient concentrations, as well as oxygen concentrations and temperature were expected.

Figure 6. Exemplary vertical orofiles for nhosohate - phosphorus (PO $-P$ ) and dissolved $\mathrm{O}_{2}$ in U.S. slope water (2), a warm core eddy (14), the Sargasso sea (13), and Scotian slope water (14)

$$
\mathrm{PO}_{4} \text { - } \mathrm{P} \text { in ug - at/L }
$$
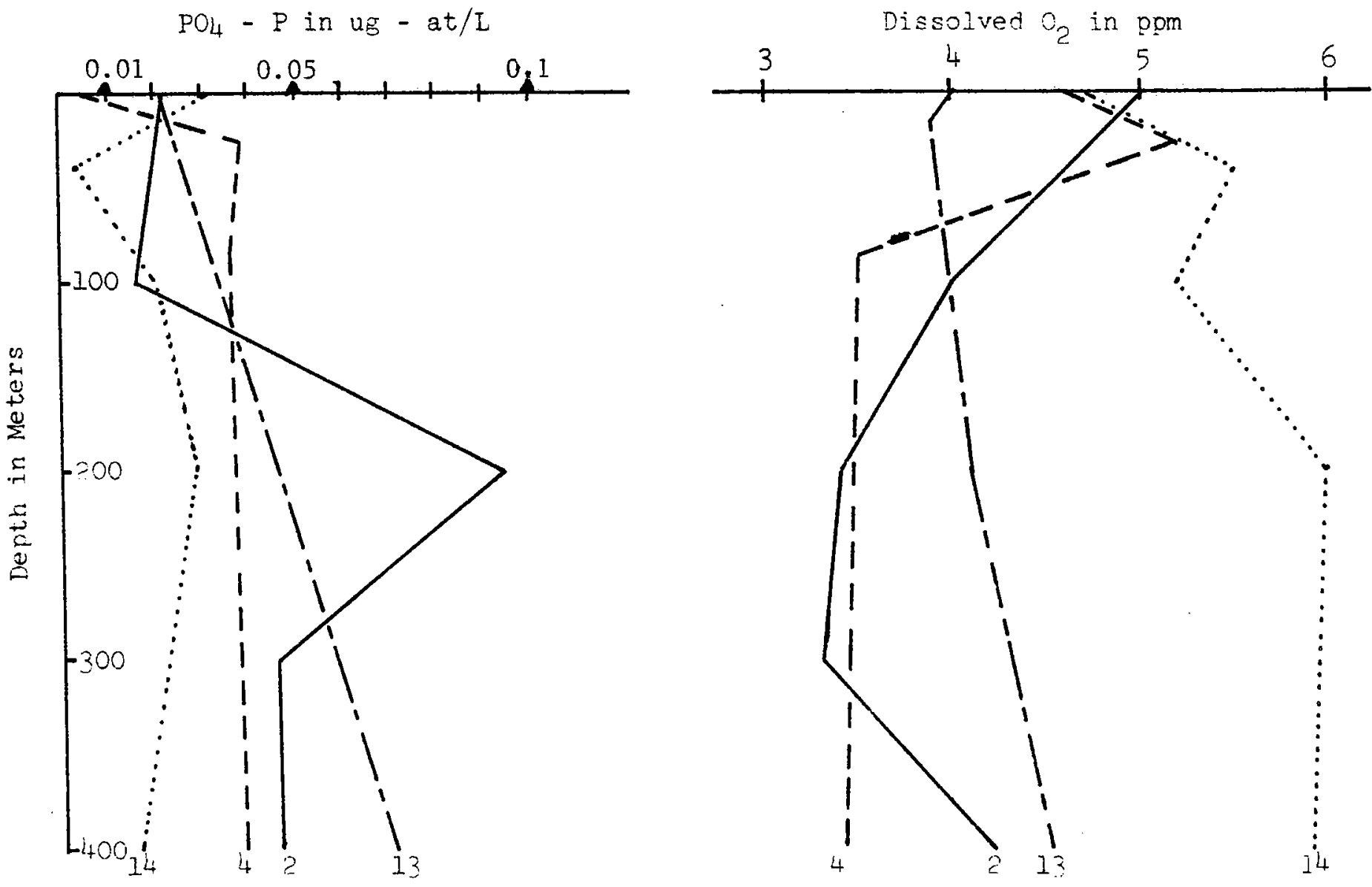
The data showed the general trend of relatively lower nutrient concentrations in the surface waters with marked increases below the thermocline. In addition, extremely low nutrient levels were evident in the Sargasso Sea in comparison to the Atlantic shelf and slope. Diurnal fluctuations of nutrient levels were noted in the warm core eddy. Lastly, inverse correlations between oxygen and nutrient concentrations, and oxygen and temperature prevailed at nearly all stations. Hach Kit measurement of nutrients at these low levels required standardization with known solutions to bring readings within realistic ranges. (See Figure 6)

3) A Comparison of Extinction Coefficient Measurements Taken with a Secchi Disc and a Submarine Photometer (Glasser)

\section{Abstract}

The transparancy of sea water is controlled by the inherant scattering and absorption nature of the water molecules, the presence of dissolved colored substances, and the presence of suspended particulate matter. The secchi disc depth, the depth of disappearance of this disc, is an indicator of transparancy. The submarine photometer (Kahl Mod 268 WA 310 Irradiometer) readings were used as a standard. The percentage of total incident light at any depth was designated \% . The coefficient of extinction $(k)$ is the rate of decrease of downward radiation. The formula used for photometer readings was $k=$ (In $I_{0}-$ In $I_{d}$ )/d, where $I_{0}=$ ambient light intensity, $I_{d}=$ light intensity at any depth, and $d=$ actual depth of sub-surface photo cell. For the secchi disc measurements, $k=1.7 / \mathrm{d}$, where $d$ is the length of secchi disc line out at disappearance. The values

Table 6. Comparison of $\%$ light intensities (\%I) and coefficients of extinction (k) derived from Secchi disc and submarine photometer measurements

\begin{tabular}{|c|c|c|c|c|c|c|c|c|c|c|}
\hline 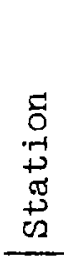 & $\begin{array}{l}0 \\
+ \\
\tilde{\Xi} \\
\oplus\end{array}$ & 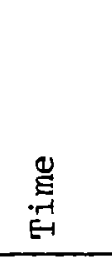 & 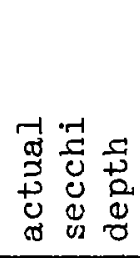 & 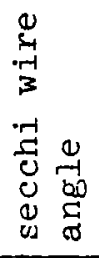 & 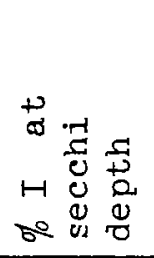 & 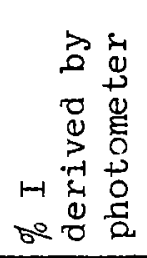 & 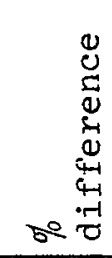 & $\begin{array}{l} \pm 1 \\
-1 \\
0 \\
0 \\
0 \\
0 \\
02\end{array}$ & 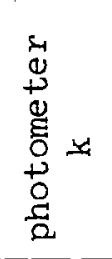 & 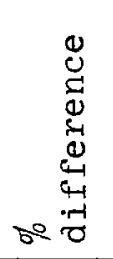 \\
\hline 1 & $7 / 30 / 78$ & 0823 & 10.61 & $45^{\circ}$ & 10.70 & 9.35 & 12.6 & .149 & .200 & 25.5 \\
\hline 2 & $7 / 30 / 78$ & 1525 & 18.61 & $40^{\circ}$ & 12.38 & 1.50 & 87.6 & .091 & .200 & 54.5 \\
\hline 3 & $8 / 02 / 78$ & 1030 & 22.28 & $50^{\circ}$ & 9.07 & 4.90 & 46.0 & .060 & .110 & 45.5 \\
\hline $\overrightarrow{4}$ & $8 / 02 / 78$ & 1640 & 34.03 & $15^{\circ}$ & 17.32 & 1.00 & 94.2 & .050 & .075 & 33.3 \\
\hline 5 & $8 / 06 / 78$ & 1500 & 33.86 & $30^{\circ}$ & 14.88 & 2.00 & 86.6 & .050 & .080 & 37.5 \\
\hline 6 & $8 / 07 / 78$ & 1015 & 19.01 & $45^{\circ}$ & 10.77 & 3.50 & 67.5 & .089 & .160 & 44.4 \\
\hline 7 & $8 / 07 / 78$ & 1700 & 26.61 & $45^{\circ}$ & 10.64 & 0.35 & 96.7 & .064 & .220 & 70.9 \\
\hline 8 & $8 / 14 / 78$ & 1345 & 23.57 & $45^{\circ}$ & 10.74 & 4.50 & 58.1 & .072 & .270 & 46.6 \\
\hline 9 & $8 / 15 / 78$ & 0800 & 31.00 & $0^{\circ}$ & 18.21 & 3.50 & 80.8 & .055 & .099 & 44.4 \\
\hline
\end{tabular}


for \% I extrapolated fromsecchi disc depths were consistently higher, and for $k$ consistently lower, than those derived for equivalent depths using the photometer. Calculating the per cent difference between the secchi and photometer values gave results ranging from 12.6 to $96.7 \%$ for $\% \mathrm{I}$, and from 25.5 to $70.9 \%$ for $\mathrm{k}$. The secchi depth $\% \mathrm{I}$ values were directly affected by the wire angle of the secchi line. The \%I at a line angle of $0^{\circ}$ was 18.21 , and at a line angle of $50^{\circ}, 9.07$. It is evident that the secchi disc formula for calculating $k$ requires an additional factor to allow for wire angle of the line. Another possible factor would be sea state, but there was insufficient data to measure its effect. (See Table 6)

4) The Effect of Surface Thermal Changes on Weather in the Western North Atlantic (Morss)

\section{$\underline{\text { Abstract }}$}

The effect of surface temperature changes on the air masses above them was studied. Since the sea has a relatively simpler surface than land masses, features affecting the air above the sea were easy to isolate. A graph showing water and atmospheric conditions was maintained from July 27 to Aug. 21, as Westward tracked from Woods Hole to Bermuda, and thence to Sable Island, Nova Scotia. This graph revealed two related water and air masses: a semitropical Sargasso Sea system and a cool slope and coastal system. The most interesting features were the stationary fronts that lie at the Gulf Stream and warm core eddy edges. Radar plots and drawings were used to study individual squalls, while a weatherfax machine gave information on large scale systems. Overall, there was strong evidence that surface contrasts play an important role in controlling the weather on a large and small scale basis. (See Figure 7)

Figure 7. NOAA satellite analysis depicting standing cold front at southern edge of Gulf Stream

G.S.

SLii

SH:I

C.E.

W.E.

0000

$\underset{-\infty}{-0}$
GULF STREAMA

SLQPE YATER

SHELF WATER

COLD EODY

VIA.:. EDOY

LliilT OF OBSERVATION

SHARP THERIIIAL GRADIEIIT

LESS DISTINCT THERMAL FROMT

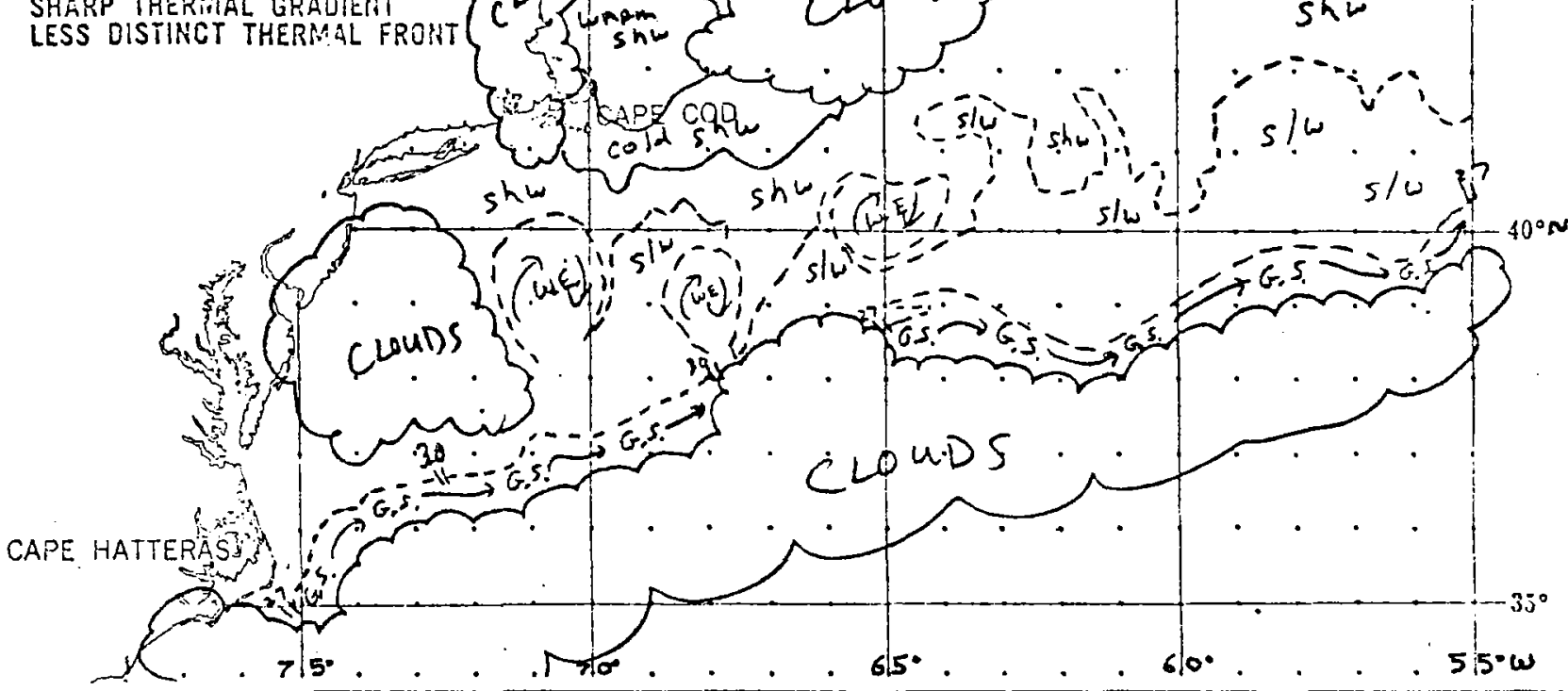


H. Miscellaneous Studies and Observations

1)A roster of coral reef fishes sighted on a diving field trip to Castle Rock on the island of Bermuda is presented in Appendix 5. These sighting rosters will be maintained on a visit to visit basis in order to monitor any noteworthy changes in the indigenous reef fish populations.

2) Three otter trawls were taken at selected sites off the U.S. and Scotian coast in order to demonstrate the epibenthic fauna to the students. Long term monitoring on a seasonal and annual basis will provide information on changes in these communities. (See Appendix 6 for species rosters)

3) Two students, Marion Valpey and Brad Gandrup, conducted a study not strictly related to marine science, but nevertheless of a technical nature. The results of their investigation into the accuracy of life boat navigation techniques are presented below.

\section{Abstract}

Experiments in Life Boat Navigation (Valpey and Gandrup)

The objective of this study was to test some of the techniques involved in life boat navigation and thereby gain a working knowledge of their practical application and relative value. The tests were made using methods of varying degrees of sophistocation and this information was compared with Westward's own navigational data. The experiments included: the use of a chip $10 g$ and Dutchman's $10 \mathrm{~g}$, and the ship's compass for two DR plots; declination by approximation; longitude by simulus; and altitude measurements of celestial bodies using the life boat sextants (Ebbco - plastic) and two primative astrolabes.

Results showed the chip and Dutchman's logs to vary in accuracy by as much as four knots according to the ship's point of sail, though this was partially attributed to faulty methodology. Approximated declinations proved accurate to within 10.6'. The plastic sextant and longitude by simulus were nearly as reliable, being in error on the average by $10.4^{\prime}$ and $170^{\prime}$, respectively. The astrolabes, though functionally accurate to approximately one degree of arc, are still deemed much more valuable than nothing at all. Results with all the tools and techniques showed that accuracy improved substantially with practice.

III. Visiting Investigator Programs

A. Seabird Observations

Two separate visiting ornithologists, Miss Patricia McGill and 
Mr Timothy Rumage, accompanied Westward on W 41, Legs I and III, respectively. Their reports on seabird observations, together with that of students, Josie Quintrell and Carolyn Steiner, appear below.

1) Bird Observations from Four Western North Atlantic Water Masses (McGil1)

\section{Abstract}

During cruise $W 41$ of $R / V$ Westward from Woods Hole to St. George, Bermuda (July 27 to Aug. 8, 1978), bird observations were recorded during 15 minute periods spaced throughout the day. There were at least five and up to 14 observation periods per day, for a total of 108. Each daylight hour was sampled between five and nine times. During each observation period the following information was recorded: species and number of birds, direction of travel and general behavior; sea and weather conditions, barometric pressure, surface water temperature, water depth, and location of the ship. In addition to observations during hourly periods, all other casual bird observations were recorded.

An attempt was made to make adequate samples of birds found in all water masses crossed by the ship. The ship spent different amounts of time in different water masses, and the number of observations reflects this: continental shelf and slope waters - 29 observation periods in 59 hours; warm core eddy - 20 periods in 36 hours; Gulf Stream - 5 periods in 14 hours; and Sargasso Sea - 53 periods in 171 hours.

Preliminary analysis of the data indicates that the water masses are characterized to some extent by the birds found there. The most common birds of the shelf and slope waters were the Greater Shearwater and Wilson's Petrel. Both Herring and Great Black-backed Gulls were also seen in this area, although they disappeared after the first 12 hours. Petrels did not appear until after this initial period. While the most common bird of the warm core eddy was again Wilson's Petrel, shearwaters were rarely seen in this area. Gulf Stream waters, on the other hand, were characterized by shearwaters, primarilly Greater, but also Cory's, Audubon's and Sooty. At one time a congregation of 75 to 100 shearwaters was seen. The Sargasso Sea showed a striking difference in local birds seen. Three shearwaters were seen in the first few hours. Following that, only whitetailed Tropicbirds were seen.

Further analysis of these data will attempt to correlate bird distributions with water depth, time of day, distance from shore and weather conditions. It appears that water masses may have indicator bird species. Closer analysis of these data and repeated data collection on similar cruises may lead to more refined conclusions. 
2) Population Dynamics of Pelagic Birds (Rumage)

Abstract

The study conducted on $W 41$ is part of a long term project on seabird ecology. The aim of the research effort is to test potential correlations of meteorological data, productivity levels and distance from land with intra- (based on age class) and interspecific diversity and abundance.

Preliminary results from $W 41$ demonstrate a sharp demarcation between coastal-marine (i.e. Herring Gull) and true pelagic (i.e. Greater Shearwater) species based on water mass parameters. Those species that could be aged by plumage had a bimodal distribution pattern with a significantly higher proportion of subadults found in the intermediate water zones, areas of relatively low productivity and inside the 50 fathom contour, than in more productive areas.

The stage of wing molt in Greater Shearwaters was recorded, as were different modes of prey catching behavior exhibited by that species. Behavioral interactions of rafting Greater Shearwaters were noted and their vocalizations recorded.

3) Diversity and Population Density of Pelagic Birds as They Relate to Water. Máss Productivity (Quintre1l and Steiner)

\section{Abstract}

This study focused on the relationship between the productivity of water masses and pelagic bird diversity and population density. Highly productive waters would be expected to support communities of greater density and diversity than in waters of relatively low productivity.

Bird watches were conducted for'a total of an hour per day in four fifteen minute intervals. The number of individuals and species, and the ship's position were recorded for each sighting. Productivity data in the form of biomass of neuston fish and subsurface zooplankton were collected from other student's projects. A relatively high diversity and dense populations of pelagic birds characterized the waters north of the Gulf Stream, in contrast to sparce populations and low diversity found in the Sargasso Sea. Although bird populations showed a general increase in density and diversity with proximity to continental land masses, it was not possible to distinguish the direct effects, of productivity on these birds. This may be attributed to the lack of precise coincidence between sighting periods and productivity sampling. (See Table 7) 
Table 7.

W-4I Bird Sightings

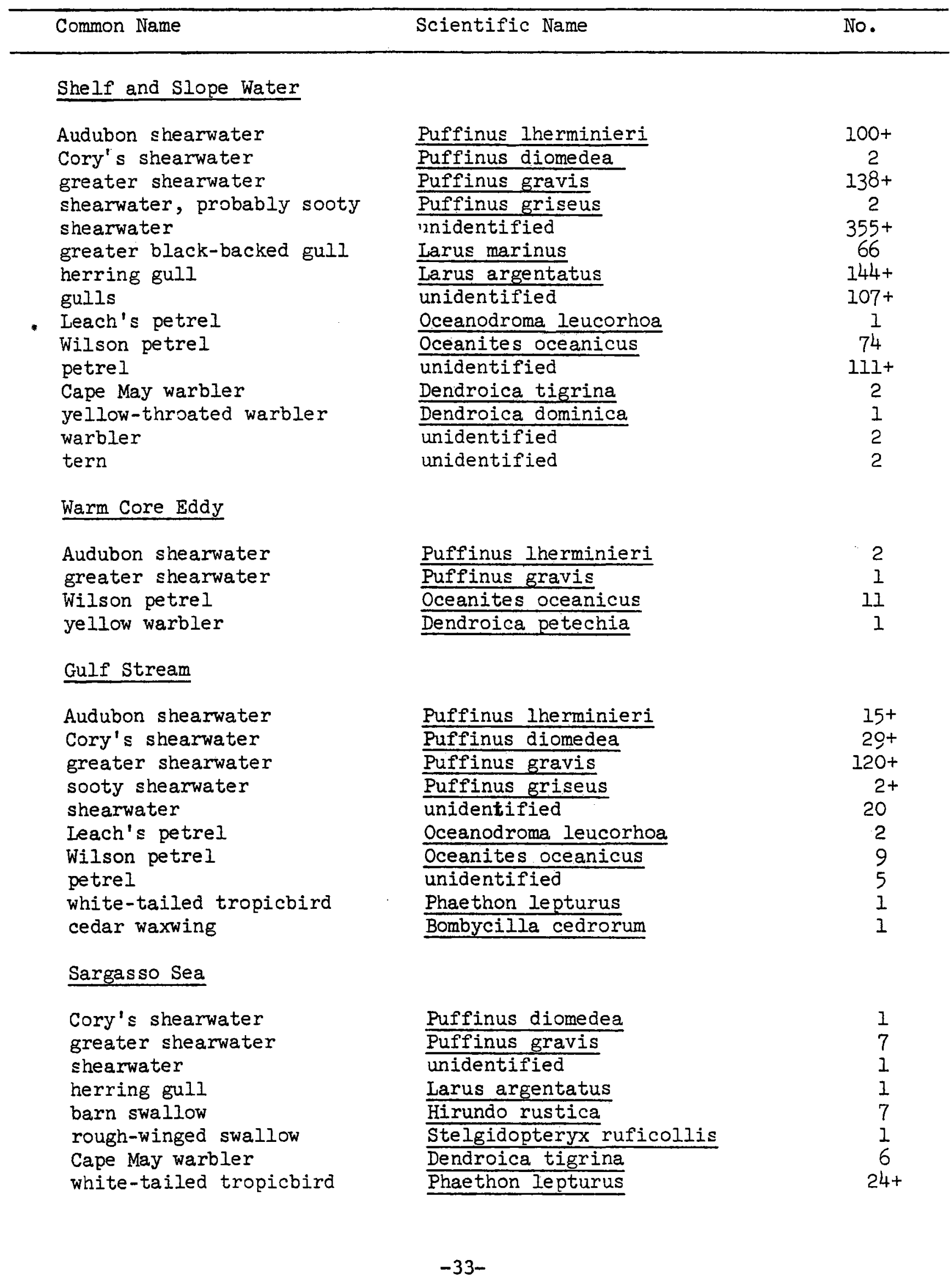


B. Fish Pathology Studies

A visiting veterinary student, Mr. Edward Robb, made use of the various fishes collected during Leg II of W 41 in order to investigate the extent of pathological conditions in these pelagic forms. His report follows.

1) Pathology of Some Pelagic Fishes Collected in the Western North Atlantic (Robb)

Through a combination of otter trawls, Isaacs-Kidd midwater trawls, and trolling, various pelagic fishes were collected for observation of gross pathological lesions (ulcers, fin rot, lymphocystis, cauliflower disease, black spot, reversal and skeletal abnormalities). Necropsies of the following species were initiated: Histrio histrio, myctophidae (two species), Thunnus thynnus, Myoxocephalus octodecemspinosus, Hippoglossoides plattessoides, Limanda ferruginea, and Raja radiata. Parasitic copepods, trematodes, and cestodes were routinely found. other tissues were fixed in formalin for histopathological study on shore. 
Appendix 1

Summary Logs of Major Stations

\begin{tabular}{|c|c|c|c|c|c|c|c|}
\hline Operation & $\#$ & Date & Time & Depth & Lat $(\mathrm{N})$ & Long (W) & Notes \\
\hline Hydrocasts & $\begin{array}{l}1 \\
2 \\
3 \\
4 \\
5 \\
6 \\
7 \\
8 \\
9 \\
10 \\
11 \\
12 \\
13 \\
14\end{array}$ & $\begin{array}{l}28 \text { July } \\
29 \text { July } \\
29 \text { July } \\
30 \text { July } \\
30 \text { July } \\
30 \text { July } \\
1 \text { Aug } \\
4 \text { Aug } \\
11 \text { Aug } \\
14 \text { Aug } \\
14 \text { Aug } \\
15 \text { Aug } \\
15 \text { Aug } \\
17 \text { Aug }\end{array}$ & $\begin{array}{l}1200 \\
0000 \\
2040 \\
0207 \\
0812 \\
1430 \\
2020 \\
2143 \\
2115 \\
1355 \\
2016 \\
0206 \\
0806 \\
2035\end{array}$ & $\begin{array}{l}100 \mathrm{M} \\
400 \mathrm{M} \\
400 \mathrm{M} \\
400 \mathrm{M} \\
400 \mathrm{M} \\
400 \mathrm{M} \\
200 \mathrm{M} \\
400 \mathrm{M} \\
400 \mathrm{M} \\
400 \mathrm{M} \\
400 \mathrm{M} \\
400 \mathrm{M} \\
400 \mathrm{M} \\
400 \mathrm{M}\end{array}$ & $\begin{array}{l}40^{\circ} 06^{\prime} \\
39^{\circ} 49^{\prime} \\
38^{\circ} 33^{\prime} \\
38^{\circ} 33^{\prime} \\
38^{\circ} 31^{\prime} \\
38^{\circ} 33^{\prime} \\
36^{\circ} 56^{\prime} \\
34^{\circ} 00^{\prime} \\
34^{\circ} 07^{\prime} \\
37^{\circ} 7^{\prime} \\
37^{\circ} 43^{\prime} \\
37^{\circ} 42^{\prime} \\
37^{\circ} 46^{\prime} \\
41^{\circ} 38^{\prime}\end{array}$ & $\begin{array}{l}69^{\circ} 51^{\prime} \\
69^{\circ} 40^{\prime} \\
70^{\circ} 08^{\prime} \\
70^{\circ} 08^{\prime} \\
70^{\circ} 11^{\prime} \\
70^{\circ} 08^{\prime} \\
66^{\circ} 25^{\prime} \\
66^{\circ} 31^{\prime} \\
64^{\circ} 33^{\prime} \\
62^{\circ} 35^{\prime} \\
62^{\circ} 29^{\prime} \\
62^{\circ} 33^{\prime} \\
62^{\circ} 36^{\prime} \\
61^{\circ} 42^{\prime}\end{array}$ & $\begin{array}{l}\text { Diel Sta. 1-1 } \\
\text { Diel Sta. 1-2 } \\
\text { Diel Sta. 1-3 } \\
\text { Diel Sta. 1-4 } \\
\text { Eel Sta. } \\
\text { Eel Sta. } \\
\text { Eel Sta. } \\
\text { Diel Sta. 2-1 } \\
\text { Diel Sta. 2-2 } \\
\text { Diel Sta. 2-3 } \\
\text { Diel Sta. 2-4 } \\
\text { Eel Sta. }\end{array}$ \\
\hline $\begin{array}{l}\text { Isaacs-Kidd } \\
\text { Midwater } \\
\text { Trawls } \\
\text { (IKMT) }\end{array}$ & $\begin{array}{l}1 \\
2 \\
3 \\
4 \\
5 \\
6\end{array}$ & $\begin{array}{l}31 \text { July } \\
2 \text { Aug } \\
10 \text { Aug } \\
15 \text { Aug } \\
16 \text { Aug } \\
18 \text { Aug }\end{array}$ & $\begin{array}{l}2233 \\
2005 \\
2138 \\
0035 \\
2250 \\
2130\end{array}$ & $\begin{array}{l}600 \mathrm{M} \\
600 \mathrm{M} \\
600 \mathrm{M} \\
600 \mathrm{M} \\
600 \mathrm{M} \\
600 \mathrm{M}\end{array}$ & $\begin{array}{l}37^{\circ} 32^{\prime} \\
36^{\circ} 02^{\prime} \\
32^{\circ} 34^{\prime} \\
38^{\circ} 18^{\prime} \\
40^{\circ} 07^{\prime} \\
42^{\circ} 59^{\prime}\end{array}$ & $\begin{array}{l}68^{\circ} 07^{\prime} \\
66^{\circ} 00^{\prime} \\
64^{\circ} 33^{\prime} \\
62^{\circ} 22^{\prime} \\
61^{\circ} 51^{\prime} \\
60^{\circ} 32^{\prime}\end{array}$ & \\
\hline $\begin{array}{l}\text { Diel } \\
\text { Stations }\end{array}$ & $\begin{array}{l}1 \\
2\end{array}$ & $\begin{array}{l}29 \text { July } \\
\text { to } 30 \text { July } \\
14 \text { Aug } \\
\text { to } 15 \text { Aug }\end{array}$ & $\begin{array}{l}2000 \\
1800 \\
1400 \\
1100\end{array}$ & $\begin{array}{l}400 \mathrm{M} \\
400 \mathrm{M}\end{array}$ & $\begin{array}{l}38^{\circ} 33^{\prime} \\
37^{\circ} 47^{\prime}\end{array}$ & $\begin{array}{l}70^{\circ} 08^{\prime} \\
62^{\circ} 35^{\prime}\end{array}$ & \\
\hline $\begin{array}{l}\text { Eel } \\
\text { Stations }\end{array}$ & $\begin{array}{l}1 \\
2 \\
3 \\
4 \\
5\end{array}$ & $\begin{array}{l}29 \text { July } \\
1 \text { Aug } \\
4 \text { Aug } \\
11 \text { Aug } \\
17 \text { Aug }\end{array}$ & $\begin{array}{l}0240 \\
2135 \\
2300 \\
2255 \\
2140\end{array}$ & $\begin{array}{l}\text { To } \\
100 \mathrm{M} \\
\text { (Nets) } \\
1\end{array}$ & $\begin{array}{l}39^{\circ} 45^{\prime} \\
36^{\circ} 56^{\prime} \\
34^{\circ} 09^{\prime} \\
34^{\circ} 14^{\prime} \\
41^{\circ} 38^{\prime}\end{array}$ & $\begin{array}{l}69^{\circ} 35^{\prime} \\
66^{\circ} 25^{\prime} \\
66^{\circ} 31^{\prime} \\
64^{\circ} 27^{\prime} \\
61^{\circ} 45^{\prime}\end{array}$ & \\
\hline $\begin{array}{l}\text { Neuston } \\
\text { Tows }\end{array}$ & $\begin{array}{l}1 \\
2 \\
3 \\
4 \\
5 \\
6 \\
7 \\
8 \\
9 \\
10 \\
11 \\
12 \\
13 \\
14\end{array}$ & $\begin{array}{l}30 \text { July } \\
31 \text { July } \\
1 \text { Aug } \\
2 \text { Aug } \\
4 \text { Aug } \\
4 \text { Aug } \\
5 \text { Aug } \\
6 \text { Aug } \\
6 \text { Aug } \\
7 \text { Aug } \\
7 \text { Aug } \\
7 \text { Aug } \\
8 \text { Aug } \\
12 \text { Aug }\end{array}$ & $\begin{array}{l}2122 \\
1715 \\
1420 \\
0455 \\
0027 \\
1810 \\
1315 \\
2240 \\
1910 \\
0753 \\
1340 \\
1930 \\
0150 \\
1352\end{array}$ & & $\begin{array}{l}38^{\circ} 27^{\prime} \\
37^{\circ} 46^{\prime} \\
37^{\circ} 01^{\prime} \\
36^{\circ} 47^{\prime} \\
34^{\circ} 30^{\prime} \\
34^{\circ} 10^{\prime} \\
34^{\circ} 09^{\prime} \\
33^{\circ} 58^{\prime} \\
32^{\circ} 46^{\prime} \\
32^{\circ} 38^{\prime} \\
32^{\circ} 18^{\prime} \\
32^{\circ} 09^{\prime} \\
32^{\circ} 19^{\prime} \\
35^{\circ} 00^{\prime}\end{array}$ & $\begin{array}{l}70^{\circ} 07^{\prime} \\
68^{\circ} 36^{\prime} \\
66^{\circ} 54^{\prime} \\
66^{\circ} 05^{\prime} \\
66^{\circ} 31^{\prime} \\
66^{\circ} 19^{\prime} \\
66^{\circ} 08^{\prime} \\
66^{\circ} 38^{\prime} \\
64^{\circ} 59^{\prime} \\
64^{\circ} 43^{\prime} \\
65^{\circ} 22^{\prime} \\
64^{\circ} 49^{\prime} \\
64^{\circ} 38^{\prime} \\
64^{\circ} 31^{\prime}\end{array}$ & \\
\hline
\end{tabular}


(Summary Logs of Major Stations Cont.)

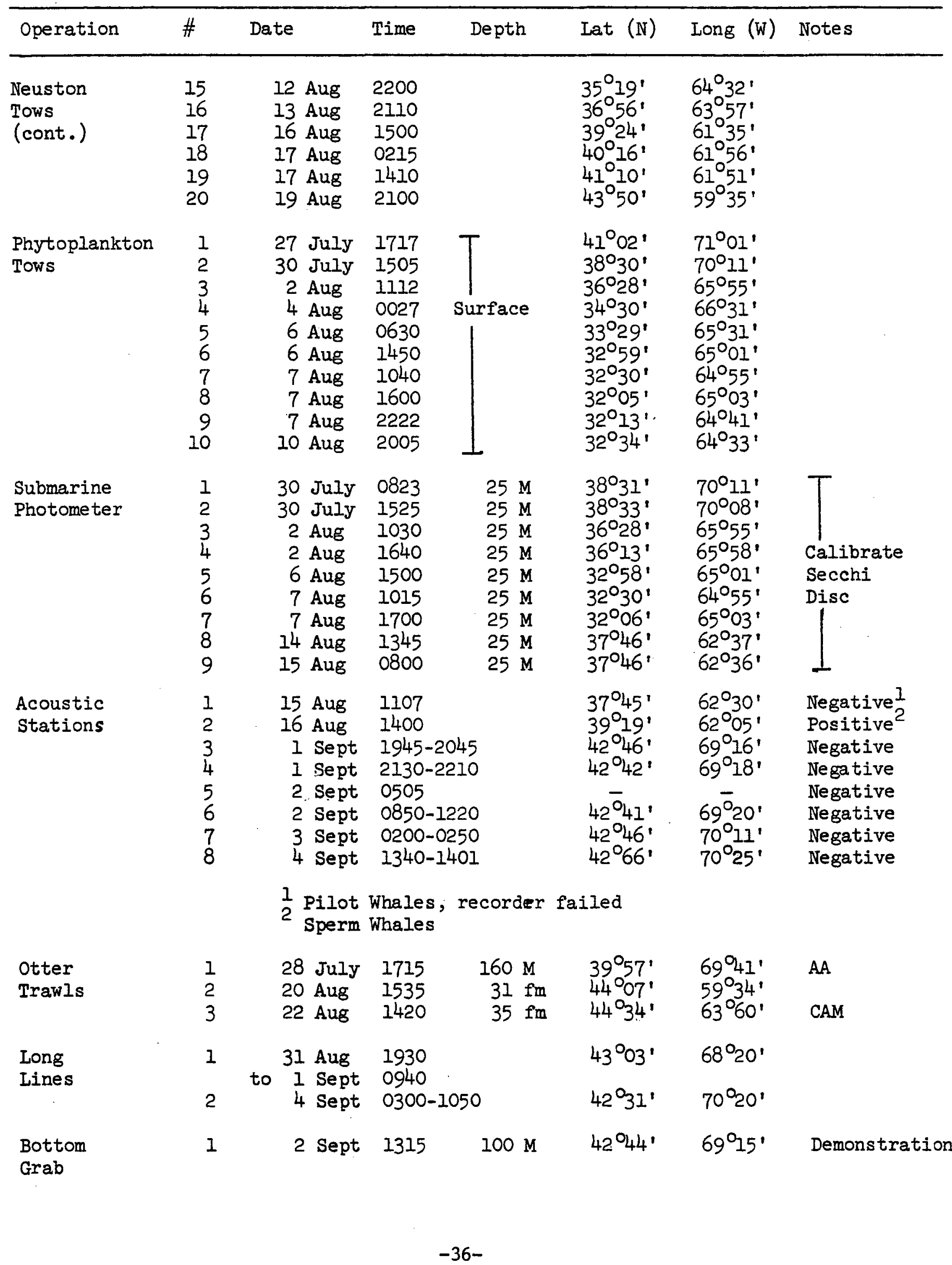


(Summary Logs of Major Stations Cont.)

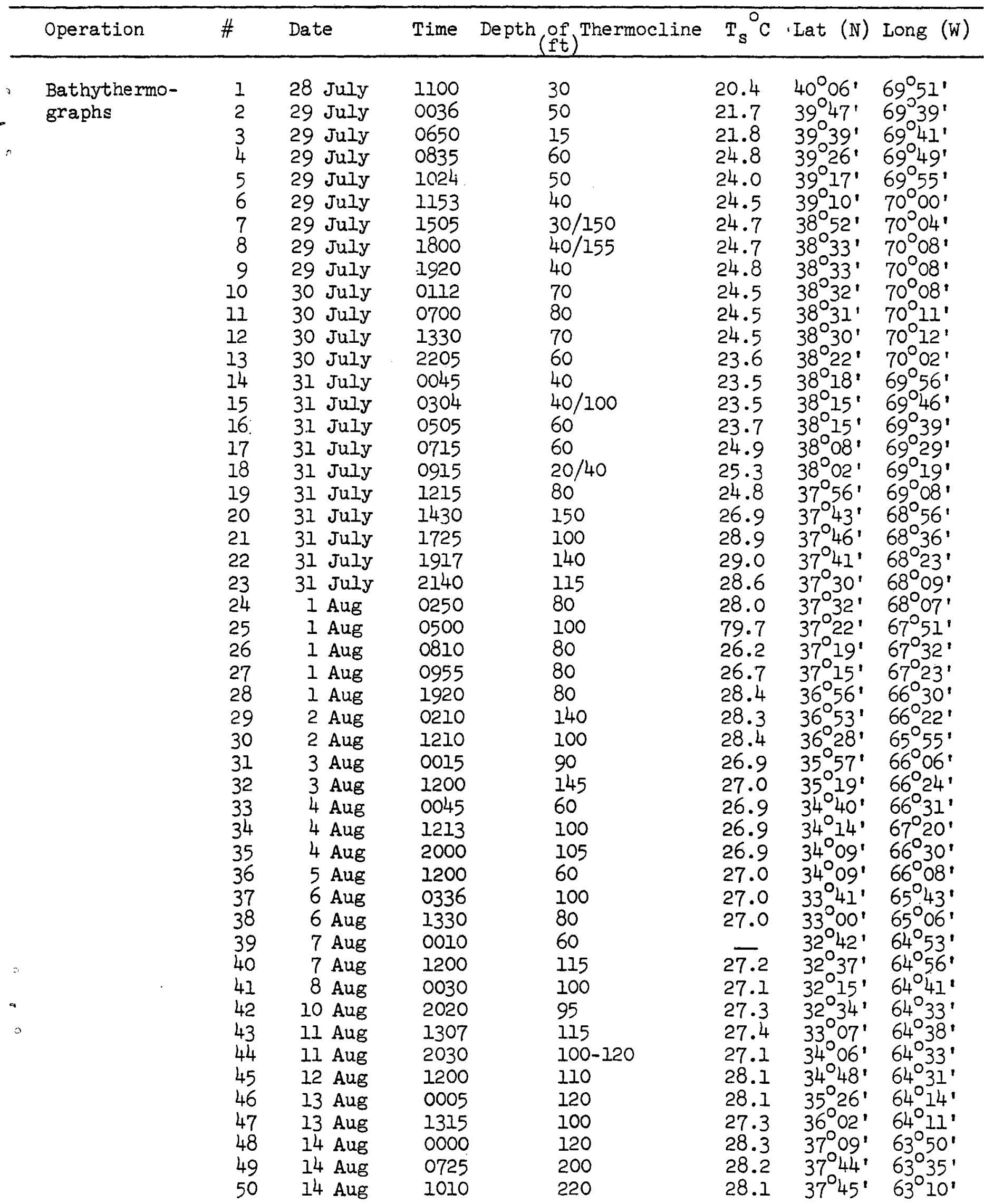


(Summary Logs of Major Stations Cont.)

\begin{tabular}{|c|c|c|c|c|c|c|c|}
\hline Operation & $\#$ & Date & Time & Depth $\begin{array}{c}\text { of } \\
\text { (ft) }\end{array}$ & $\mathrm{T}_{\mathrm{s}}{ }^{\circ} \mathrm{C}$ & Lat $(\mathrm{N})$ & Long (W) \\
\hline $\begin{array}{l}\text { Bathythermo- } \\
\text { graphs } \\
\text { (cont.) }\end{array}$ & $\begin{array}{l}51 \\
52 \\
53 \\
54 \\
55 \\
56 \\
57 \\
58 \\
59 \\
60 \\
61 \\
62 \\
63 \\
64 \\
65 \\
66 \\
67 \\
68 \\
69 \\
70 \\
71 \\
72 \\
73 \\
74 \\
75 \\
76 \\
77\end{array}$ & $\begin{array}{l}14 \text { Aug } \\
14 \text { Aug } \\
14 \text { Aug } \\
15 \text { Aug } \\
15 \text { Aug } \\
15 \text { Aug } \\
15 \text { Aug } \\
15 \text { Aug } \\
15 \text { Aug } \\
15 \text { Aug } \\
16 \text { Aug } \\
16 \text { Aug } \\
16 \text { Aug } \\
16 \text { Aug } \\
16 \text { Aug } \\
16 \text { Aug } \\
16 \text { Aug } \\
16 \text { Aug } \\
16 \text { Aug } \\
16 \text { Aug } \\
17 \text { Aug } \\
17 \text { Aug } \\
17 \text { Aug } \\
17 \text { Aug } \\
18 \text { Aug } \\
19 \text { Aug } \\
19 \text { Aug }\end{array}$ & $\begin{array}{l}1200 \\
1300 \\
1950 \\
0105 \\
0710 \\
1210 \\
1410 \\
1700 \\
1910 \\
2100 \\
0000 \\
0427 \\
0615 \\
0800 \\
1020 \\
1300 \\
1505 \\
1715 \\
1842 \\
2145 \\
0245 \\
0510 \\
1200 \\
1900 \\
1200 \\
0105 \\
1215\end{array}$ & $\begin{array}{l}160 \\
160 \\
160 \\
160 \\
240 \\
180 \\
140 \\
180 \\
200 \\
220 \\
250 \\
260 \\
260 \\
220 \\
180 \\
140 \\
150 \\
120 \\
100 \\
95 \\
260 \\
50 / 125 \\
55 \\
120 \\
65 \\
65 \\
60\end{array}$ & $\begin{array}{l}28.4 \\
28.5 \\
28.4 \\
28.4 \\
28.5 \\
28.5 \\
28.5 \\
28.5 \\
28.4 \\
28.3 \\
28.4 \\
28.4 \\
28.4 \\
28.0 \\
28.3 \\
29.7 \\
29.0 \\
28.3 \\
25.6 \\
25.5 \\
25.1 \\
24.5 \\
24.1 \\
24.1 \\
23.2 \\
22.4 \\
20.3\end{array}$ & $\begin{array}{l}37^{\circ} 46^{\prime} \\
37^{\circ} 46^{\prime} \\
37^{\circ} 4^{\prime} 4^{\prime} \\
37^{\circ} 4^{\prime} \\
37^{\circ} 4^{\prime} 6^{\prime} \\
37^{\circ} 4^{\prime} 4^{\prime} \\
37^{\circ} 4^{\prime} 1^{\prime} \\
37^{\circ} 37^{\prime} \\
37^{\circ} 4^{\prime} \\
38^{\circ} 4^{\prime}, \\
38^{\circ} 18^{\prime} \\
38^{\circ} 24^{\prime} \\
38^{\circ} 35^{\prime} \\
38^{\circ} 46^{\prime} \\
39^{\circ} 00^{\prime} \\
39^{\circ} 12^{\prime} \\
39^{\circ} 24^{\prime} \\
39^{\circ} 27^{\prime} \\
39^{\circ} 1^{\prime} \\
39^{\circ} 57^{\prime} \\
40^{\circ} 16^{\prime} \\
40^{\circ} 30^{\prime} \\
41^{\circ} 26^{\prime} \\
41^{\circ} 26^{\prime} \\
42^{\circ} 27^{\prime} \\
43^{\circ} 00^{\prime} \\
43^{\circ} 29^{\prime}\end{array}$ & $\begin{array}{l}62^{\circ} 42^{\prime} \\
62^{\circ} 37^{\prime} \\
62^{\circ} 31^{\prime} \\
62^{\circ} 34^{\prime} \\
62^{\circ} 38^{\prime} \\
62^{\circ} 29^{\prime} \\
62^{\circ} 28^{\prime} \\
62^{\circ} 27^{\prime} \\
62^{\circ} 26^{\prime} \\
62^{\circ} 24^{\prime} \\
62^{\circ} 22^{\prime} \\
62^{\circ} 17^{\prime} \\
62^{\circ} 07^{\prime} \\
61^{\circ} 57^{\prime} \\
61^{\circ} 58^{\prime} \\
61^{\circ} 46^{\prime} \\
61^{\circ} 35^{\prime} \\
61^{\circ} 38^{\prime} \\
61^{\circ} 44^{\prime} \\
61^{\circ} 48^{\prime} \\
61^{\circ} 56^{\prime} \\
61^{\circ} 56^{\prime} \\
61^{\circ} 32^{\prime} \\
61^{\circ} 32^{\prime} \\
60^{\circ} 4^{\prime} 9^{\prime} \\
60^{\circ} 32^{\prime} \\
59^{\circ} 4^{\prime} 7^{\prime}\end{array}$ \\
\hline
\end{tabular}


W-41 Biological Teaching Collection

Organism Common Name Source

Phylum Arthropoda

Eupagurus bernharedus

Acanthephyra purpurea

Phronima sp.

Palinurus sp.

Lepas hilli

Halobates micans

Euphausia hemigibba

Phylum Chaetognatha

Sagitta elegans

Phylum Chordata

Paraxeno mystax

Pyrosoma atlanticum

Histrio histrio

Physeter catodon

Thalia democratica

Ceratoscopelus sp.

Puffinus gravis

Phylum Coelenterata

Hippopodius hippopus

Phylum Ctenophora

Pleurobrachia pileus

Phylum Cyanophyta

Trichodesmium sp.

Phylum Moliusca

Calliteuthis reversa

pterotrachea coronata

Cavolina trispinosa

Division Phaeophycophyta

Sargassum fluitans

Phylum Platyhelminthes

Dactylogyrus sp. hermit crab

scarlet prawn

amphipod

spiney lobster larvae

gooseneck barnacle

water strider

krill

arrow worm

eel larvae

tunicate

Sargassum fish

sperm whale

salp

lantern fish

greater shearwater

siphonophore bracts

comb jelly

bluegreen algae

pelagic squid

heteropod

pteropod

Sargassum or Gulf weed

parasitic worm
Continental Shelf

warm core eddy

Gulf Stream

Gulf Stream

drifting bottle

Neuston

Sargasso Sea

cosmopolitan

warm core eddy

Sargasso Sea

Sargasso Sea

Gulf Stream edge

slope water

Western North Atlantic

north of Gulf Stream

warm core eddy

No. American coastal waters

Gulf Stream

warm core eddy

warm core eddy

Sargas so Sea

Sargasso Sea

bluefin tuna gills 
Appendix 3. W-4l Ship's weather observations

\begin{tabular}{|c|c|c|c|c|c|c|c|c|c|c|c|}
\hline $99 \mathrm{~L}_{\mathbf{a}} \mathrm{L}_{\mathbf{a}} \mathrm{L}_{\mathbf{a}}$ & $Q_{c} L_{o} I_{o} L_{o}$ & YYGGi $_{w}$ & Nddff & VVwwW & PPPTT & $\mathrm{N}_{\mathrm{h}} \mathrm{C}_{\mathrm{L}^{\mathrm{h}}} \mathrm{C}_{\mathrm{M}} \mathrm{C}_{\mathrm{H}}$ & $D_{s} v_{s} a p p$ & ${ }^{O} \mathrm{~T}_{\mathrm{s}} \mathrm{T}_{\mathrm{s}} \mathrm{T}_{\mathrm{d}} \mathrm{T}_{\mathrm{c}}$ & ${ } T_{w} T_{w} T_{w} t_{T}$ & $3 \mathrm{P}_{w} \mathrm{P}_{w} \mathrm{H}_{w} \mathrm{H}_{w}$ & $\mathrm{~d}_{w} \mathrm{~d}_{w} \mathrm{P}_{w} \mathrm{H}_{w} \mathrm{H}_{w}$ \\
\hline 89408 & $\begin{array}{l}70736 \\
70699\end{array}$ & $\begin{array}{l}28063 \\
28123\end{array}$ & $\begin{array}{l}11911 \\
62309\end{array}$ & $\begin{array}{l}98020 \\
97030\end{array}$ & $\begin{array}{l}11522 \\
10723\end{array}$ & $\begin{array}{l}10000 \\
65141\end{array}$ & $\begin{array}{l}32201 \\
41206\end{array}$ & $\begin{array}{l}00422 \\
00722\end{array}$ & $\begin{array}{l}12013 \\
11995\end{array}$ & $\begin{array}{l}3 / 111 \\
30201\end{array}$ & $\begin{array}{l}71111 \\
22702\end{array}$ \\
\hline 99380 & 70700 & 29123 & 12604 & 98030 & 11924 & 12500 & 51400 & 05022 & 12475 & 30303 & 25702 \\
\hline 99369 & 70665 & 02043 & $2 / / / 1$ & 98600 & 24027 & 91111 & 51400 & $0 / / 26$ & 12835 & $3 / 1 / 1$ & 1111 \\
\hline 99369 & 70665 & 02063 & 41707 & 98030 & 23927 & $422 / 1$ & 21400 & 05124 & 12894 & $3 / / 01$ & 111 \\
\hline 99359 & 70661 & 03063 & 20905 & 99020 & 25226 & $/ / 1 / 1$ & 51705 & 05124 & 12696 & $3 / / 00$ & $1 / 1 /$ \\
\hline 99357 & 70664 & 03123 & 11010 & 99030 & 24527 & 12200 & 41305 & 00124 & 12672 & 30201 & 15402 \\
\hline 99345 & 70665 & 04063 & 11221 & 99000 & 22926 & 11200 & 41101 & 00024 & 12688 & $3 / / 02$ & $1 / 111$ \\
\hline 99342 & 70665 & 04123 & 21413 & 98180 & 23527 & 22362 & 41109 & 00026 & 12702 & 30202 & 11054 \\
\hline 99341 & 70661 & 05063 & 12005 & 99020 & 26427 & $122 / \%$ & 51403 & 00024 & 12680 & $3 / 1 / 1$ & $1 / 111$ \\
\hline 99341 & 70666 & 05123 & 21408 & 99020 & 27327 & 21300 & 31220 & 00225 & 12698 & 30201 & 18302 \\
\hline 99338 & 70658 & 06063 & 11405 & 99020 & 27827 & 11000 & 42009 & 05024 & 12720 & $3 / 1 / 1$ & $11 \%$ \\
\hline 99335 & 70655 & 06123 & 40712 & 99030 & 27428 & 41400 & 31208 & 00224 & 12710 & 30301 & 08502 \\
\hline 99332 & 70646 & 11123 & 73312 & 98152 & 22527 & 57661 & 81400 & 00024 & 12735 & 30201 & 01502 \\
\hline 99335 & 70643 & 12063 & 61402 & 99299 & 21526 & $497 / 1$ & 81003 & 05223 & 12710 & 30000 & 99502 \\
\hline 99344 & 70643 & 12123 & 62604 & 99018 & 22026 & 28379 & 81105 & 05023 & 12695 & 30301 & 27102 \\
\hline 99355 & 70643 & 13063 & 12604 & 99000 & 21428 & $1 / 3 / /$ & 81403 & 05024 & 12831 & $3 / / 01$ & $1 / 111$ \\
\hline 99359 & 70643 & 13123 & 72507 & 98501 & 21928 & 78491 & 00106 & 05025 & 12820 & 30301 & 25602 \\
\hline 99373 & 70638 & 14063 & 82724 & 97182 & 18326 & $873 / 1$ & 82717 & 05325 & 12793 & $3 / / / /$ & $27 / 04$ \\
\hline 99377 & 70635 & 14123 & 81820 & 97632 & 17826 & $873 / /$ & 22000 & 05125 & 12821 & 30302 & 22703 \\
\hline 99388 & 70620 & 16123 & 10502 & 99050 & 20026 & 11480 & 82108 & 05520 & 12830 & 30101 & 06501 \\
\hline 99403 & 70619 & 17003 & 03102 & 99011 & 17725 & 00900 & 81708 & 00123 & 12515 & 30000 & 99501 \\
\hline 99405 & 70620 & 17173 & 13203 & 98010 & 17525 & 00001 & 81021 & 00224 & 12391 & 30000 & 19701 \\
\hline 99418 & 70612 & 18063 & 42507 & 98031 & 15524 & 00979 & 11807 & 00324 & 12349 & 30301 & 25501 \\
\hline 99430 & 70602 & 19063 & 82507 & 97022 & 13123 & $862 / /$ & 11004 & 00422 & 12147 & $3 / / / 1$ & 25501 \\
\hline 99438 & 70595 & 20063 & 11008 & 98010 & 16019 & 16400 & 11702 & 00116 & 11936 & 30201 & 21502 \\
\hline 99440 & 70596 & 20123 & 70915 & 98031 & 15519 & 65218 & 11705 & 00118 & 11958 & 30201 & 09503 \\
\hline 99444 & 70608 & 21063 & 80815 & 98022 & 13220 & $864 / /$ & 62708 & 00219 & 11913 & $3 / / 02$ & $09 / 03$ \\
\hline 99423 & 70663 & 28063 & 03210 & 99020 & 21116 & 00900 & 61208 & 00113 & 11560 & 30101 & 99501 \\
\hline 99423 & 70665 & 28123 & 10105 & 98020 & 22217 & 00018 & 31210 & 00315 & 11560 & 39901 & 24501 \\
\hline 99433 & 70675 & 29063 & 91615 & 94216 & 09917 & $8 / / / /$ & 71753 & 00315 & 11580 & $3 / / 02$ & 11111 \\
\hline 99426 & 70692 & 02063 & 12793 & 97001 & 20819 & $1 / / / /$ & 00203 & 00218 & 11845 & $3 / / 01$ & $/ / 1 /$ \\
\hline
\end{tabular}

Key: $\mathrm{L}_{\mathrm{a}} \mathrm{L}_{\mathrm{a}} \mathrm{L}_{\mathrm{a}}=$ latitude in degrees and tenths; $Q_{c}=$ quadrant of globe; $\mathrm{L}_{0} \mathrm{~L}_{0} \mathrm{~L}_{\mathrm{O}}=$ longitude in degrees and tenths; $Y Y=$ day of month; $G G=$ Greenwich mean time; $i_{W}=$ wind indicator; $N=$ total cloud amount; $\mathrm{dd}=$ wind direction; $\mathrm{ff}=$ wind speed; $\mathrm{VV}=$ visibility; $\mathrm{w}=$ = present weather; $\mathrm{W}=$ past weather; $\mathrm{PPP}=$ sea level pressure; $\mathrm{TT}=$ air temp.; $\mathrm{N}_{\mathrm{h}}=$ amount of lowest clouds; $\mathrm{C}_{\mathrm{L}}=$ type of low cloud; $\mathrm{h}=$ height of lowest clouds; $\mathrm{C}_{\mathrm{M}}=$ type of middle cloud; $\mathrm{C}_{\mathrm{H}}=$ type of high cloud; $\mathrm{D}_{\mathrm{S}}=$ course of ship; $v_{s}=$ speed of ship; a character of pressure change; $p p=$ amount of pressure change; $T_{S}=$ air-sea temp. difference; $T_{d}=$ dew point; $T_{W}=$ sea temp.; $t_{T}=$ tenths of air temp.; $P_{W}$ and $\mathrm{H}_{\mathrm{w}}=$ wind wave period and height; $\mathrm{d}_{\mathrm{w}}=$ swell direction. 
Appendix 4.

W-41 Marine Mammal Sightings

\begin{tabular}{|c|c|c|c|c|}
\hline Date & Time & Lat $(\mathrm{N})$ & Long (W) & Sighting/ I.D./ No's. \\
\hline 27 July & 1640 & $41^{\circ} 02^{\prime}$ & $71^{\circ} \mathrm{Ol}$ & Three blows: unidentified, 1 . \\
\hline 29 July & 1126 & $399^{\circ} 10^{\prime}$ & $70^{\circ} 01^{\prime}$ & Bottlenose dolphins: Tursiops truncatus, 6 . \\
\hline $30 \mathrm{JuIy}$ & 0645 & $38^{\circ} 33^{\prime}$ & $70^{\circ} 08^{\prime}$ & Saddlebacks; Delphinus delphis, 50. \\
\hline 1 Aug & 1600 & 36054 & $66^{\circ} 49^{\circ}$ & Dolphins: unidentified, 3-4. \\
\hline 15 Aug & 1107 & $37045^{\prime}$ & $62^{\circ} 30^{\prime}$ & Pilot whale: Globicephala melaena, I- 2 . \\
\hline 16 Aug & 1400 & $39^{\circ} 19^{\prime}$ & $62^{\circ} 05^{\prime} *$ & Sperm whale: Physeter catodon, 15 . \\
\hline 18 Aug & 0735 & $42^{\circ} 05^{\prime}$ & $61^{\circ} 04^{\prime}$ & $\begin{array}{l}\text { Bottlenose dolphins: Tursiops truncatus, } \\
\text { 15-20. }\end{array}$ \\
\hline 18 Aug & 1405 & $42^{\circ} 41^{\prime}$ & $60^{\circ} 51^{\prime}$ & $\begin{array}{l}\text { Striped dolphins: Stenella coeruleoalba, } \\
10^{+} \text {. }\end{array}$ \\
\hline $18 \mathrm{Aug}$ & 1630 & $42^{0} 44^{\prime}$ & $60^{\circ} 55^{\prime}$ & Dolphins: unidentified, approx. 50 \\
\hline 19 Aug & 1040 & $43^{\circ} 23^{\prime}$ & $59^{\circ} 52^{\prime}$ & Sperm whale: Physeter catodon, $I$. \\
\hline 19 Aug & 1105 & & & Possible Right whale: unidentified, 1. \\
\hline 19 Aug & 1518 & $42^{\circ} 44^{\prime}$ & $60^{\circ} 55^{\prime}$ & Striped dolphins: Stenella coeruleoalba, 3 . \\
\hline 19 Aug & 1940 & $43^{\circ} 41^{\prime}$ & $59^{\circ} 38^{\prime}$ & Pilot whales: Globicephala melaena, $5-6$. \\
\hline 20 Aug & 0715 & $43^{\circ} 59^{\prime}$ & $59^{\circ} 10^{\prime}$ & Pilot whales: Globicephala melaena, 4. \\
\hline $20 \mathrm{Aug}$ & 0730 & $43^{\circ} 59^{\prime}$ & $59^{\circ} 11^{\prime}$ & $\begin{array}{l}\text { Striped dolphins: Stenella coeruleoalba, } \\
\text { 30-40. }\end{array}$ \\
\hline 22 Aug & 1025 & $44^{\circ} 25^{\prime}$ & $63^{\circ} 59^{\prime}$ & Striped dolphins: Stenella coeruleoalba, 2. \\
\hline 22 Aug & 1410 & $44^{\circ} 34^{\prime}$ & $64^{\circ} 00^{\prime}$ & Dolphin: unidentified, 1. \\
\hline 26 Aug & 1720 & $43^{\circ} 58^{\prime}$ & $64^{\circ} 16^{\prime}$ & $\begin{array}{l}\text { Possible Pilot whales: Globicephala melaena, } \\
3 \text {. }\end{array}$ \\
\hline 27 Aug & 0720 & $43^{\circ} 01^{\prime}$ & $64^{\circ} 39^{\prime}$ & Whale: unidentified, 1 \\
\hline $27 \mathrm{Aug}$ & 0740 & $42^{\circ} 60^{\prime}$ & $64040^{\prime}$ & Whale: unidentified, $1-2$. \\
\hline 27 Aug & 0835 & $42^{\circ} 38^{\prime}$ & $64^{\circ} 40^{\prime}$ & $\begin{array}{c}\text { Possible Pilot whales: Globicephala } \\
\text { melaena, } 10^{+} \text {. }\end{array}$ \\
\hline 27 Aug & 0940 & $42^{\circ} 57^{\prime}$ & $64^{\circ} 41^{\prime}$ & Whale: unidentified, 1 . \\
\hline 27 Aug & 0950 & $42^{\circ} 57^{\prime}$ & $64^{\circ} 41^{\prime}$ & Whale: unidentified, $I$. \\
\hline 27 Aug & 1000 & $42^{\circ} 57^{\prime}$ & $64^{\circ} 41^{\prime}$ & Whale: unidentified, 1. \\
\hline 27 Aug & 1011 & $42^{\circ} 57^{\prime}$ & $64^{\circ} 41^{\prime}$ & Whales: unidentified, 3 . \\
\hline 27 Aug & 1015 & $42^{\circ} 57^{\prime}$ & $64^{\circ} 41^{\prime}$ & Whales: unidentified, 3 . \\
\hline 27 Aug & 1024 & $42^{\circ} 57^{\prime}$ & $64^{\circ} 41^{\prime}$ & $\begin{array}{c}\text { Possible Finback whales: Balaenoptera } \\
\text { physalus, } 4^{+} \text {. }\end{array}$ \\
\hline 27 Aug & 1026 & $42^{\circ} 57^{\prime}$ & $64^{\circ} 41^{\prime}$ & $\begin{array}{l}\text { Possible Finback whale: Balaenoptera } \\
\text { physalus, } 1 \text {. }\end{array}$ \\
\hline 27 Aug & 1115 & $42^{\circ} 54^{\prime}$ & $65^{\circ} 56^{\prime}$ & Whale: unidentified, 1 . \\
\hline 27 Aug & 1130 & $42^{\circ} 54^{\circ}$ & $65^{\circ} 56^{\prime}$ & Whale: unidentified, 1 . \\
\hline 27 Aug & 1140 & $42^{\circ} 54^{\prime}$ & $65^{\circ} 56^{\prime}$ & Whale: unidentified, 1. \\
\hline 27 Aug & 1150 & $42^{0} 54^{\prime}$ & $65^{\circ} 56^{\prime}$ & Whales: unidentified, 1-2. \\
\hline 27 Aug & 1158 & $42^{\circ} 54^{\prime}$ & $65^{\circ} 56^{\prime}$ & $\begin{array}{l}\text { Probably Fin whale: Balaenoptera physalus, } \\
\quad 1 .\end{array}$ \\
\hline 27 Aug & 1203 & $42^{\circ} 54^{\prime}$ & $65^{\circ} 56^{\prime}$ & Whale: unidentified, 1. \\
\hline 27 Aug & 1210 & $42^{\circ} 53^{\prime}$ & $65^{\circ} 56^{\prime}$ & Whale: unidentified, 1. \\
\hline 27 Aug! & 1215 & $42^{\circ} 53^{\prime}$ & $65^{\circ} 56^{\prime}$ & Whale: unidentified, 1. \\
\hline 27 Aug & 1230 & $42^{\circ} 53^{\prime}$ & $65^{\circ} 56^{\prime}$ & Whale: unidentified, 1. \\
\hline 27 Aug & $14 \overline{40}$ & $42^{\circ} 52^{\prime}$ & $65^{\circ} 04^{\prime}$ & Whale: unidentified, 1. \\
\hline 28 Aug & 0540 & $42^{\circ} 18^{\prime}$ & $66^{\circ} 16^{\prime}$ & Possible dolphins: unidentified, 3 . \\
\hline
\end{tabular}




\begin{tabular}{|c|c|c|c|c|}
\hline Date & Time & Lat $(W)$ & Long (W) & Sighting/ I.D./ No's. \\
\hline $\begin{array}{l}28 \text { Aug } \\
28 \text { Aug } \\
28 \text { Aug }\end{array}$ & $\begin{array}{l}1205 \\
1545 \\
1730\end{array}$ & $\begin{array}{l}42^{\circ} 45^{\prime} \\
42^{\circ} 42^{\prime} \\
42^{\circ} 45^{\prime}\end{array}$ & $\begin{array}{l}66^{\circ} 51^{\prime} \\
66^{\circ} 4_{3}^{\prime} \\
66^{\circ} 52^{\prime}\end{array}$ & $\begin{array}{l}\text { Whale: unidentified, } 1 . \\
\text { Whales: unidentified, } 2 \text {. } \\
\text { Atlantic White-sided dolphins: } \\
\text { Lagenorhynchus acutus, } 12 \text {. }\end{array}$ \\
\hline 31 Aug & 0720 & $44^{\circ} 15^{\prime}$ & $68^{\circ} 10^{\prime}$ & $\begin{array}{l}\text { Probable Minke whale: Balaenoptera } \\
\text { acutorostrata, } 1 \text {. }\end{array}$ \\
\hline 31 Aug & 1015 & $44: 001$ & $680^{\circ}$ & $\begin{array}{l}\text { Probagle Minke whale: Balaenoptera } \\
\text { acutorostrata, } 1 \text {. }\end{array}$ \\
\hline 31 Aug & 1055 & $43056^{\prime}$ & $688^{\circ} 07^{\prime}$ & $\begin{array}{l}\text { Possible Harbor porpoises: Phocoena } \\
\text { phocoena, } 2-3 \text {. }\end{array}$ \\
\hline 31 Aug & 1240 & $43^{\circ} 49^{\prime}$ & $68007^{\prime}$ & $\begin{array}{l}\text { Possible Minke whale: Balaenoptera } \\
\text { acutorostrata, } 1 \text {. }\end{array}$ \\
\hline 31 Aug & 1700 & $43^{\circ} 18^{\prime}$ & $6896^{\prime}$ & $\begin{array}{l}\text { Atlantic White-Sided dolphins: } \\
\text { Iagenorhynchus acutus, } 30^{+} \text {. }\end{array}$ \\
\hline 1 Sept & 1340 & $42054^{\prime}$ & $680^{\circ} 5^{\prime}$ & $\begin{array}{l}\text { Atlantic White-Sided dolphins: } \\
\text { Lagenorhynchus acutus, } 20-30^{+} \text {. }\end{array}$ \\
\hline $\begin{array}{l}1 \text { Sept } \\
1 \text { Sept }\end{array}$ & $\begin{array}{l}1445 \\
1537\end{array}$ & $\begin{array}{l}42^{0} 52^{\prime} \\
42^{\circ} 52^{\prime}\end{array}$ & $\begin{array}{l}68^{\circ} 54^{\prime} \\
68^{\circ} 56^{\prime}\end{array}$ & $\begin{array}{l}\text { Dolphins: unidentified, } 30-40 . \\
\text { Probable Minke whale: Balaenoptera } \\
\text { acutorostrata, } 1 .\end{array}$ \\
\hline $\begin{array}{ll}3 & \text { Sept } \\
3 & \text { Sept } \\
3 & \text { Sept } \\
3 & \text { Sept }\end{array}$ & $\begin{array}{l}1505 \\
1520 \\
1525 \\
1655\end{array}$ & $\begin{array}{l}42^{\circ} 39^{\prime} \\
42^{\circ} 39^{\prime} \\
42^{\circ} 39^{\prime} \\
42^{\circ} 35^{\prime}\end{array}$ & $\begin{array}{l}70^{\circ} 31^{\prime} \\
70^{\circ} 3 I^{\prime} \\
70^{\circ} 3 I^{\prime} \\
70^{\circ} 25^{\prime}\end{array}$ & $\begin{array}{l}\text { Whales: unidentified. } \\
\text { Whale: unidentified. } \\
\text { Whales: unidentified. } \\
\text { Humpback whale + one other species: } \\
\quad \text { Megaptera novaeangliae, } 2 \text {. }\end{array}$ \\
\hline 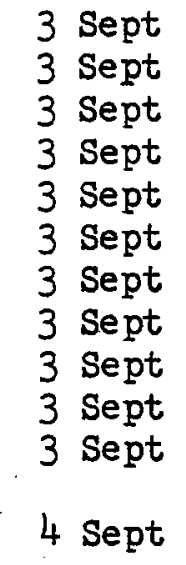 & $\begin{array}{l}1707 \\
1712 \\
1720 \\
1725 \\
1732 \\
1745 \\
1800 \\
1804 \\
1868 \\
1815 \\
1829 \\
1854 \\
1320\end{array}$ & $\begin{array}{l}42^{\circ} 35^{\prime} \\
42^{\circ} 35^{\prime} \\
42^{\circ} 35^{\prime} \\
42^{0} 35^{\prime} \\
42^{\circ} 35^{\prime} \\
42^{0} 35^{\prime} \\
42^{\circ} 35^{\prime} \\
42^{0} 35^{\prime} \\
42^{\circ} 35^{\prime} \\
42^{\circ} 35^{\prime} \\
42^{\circ} 20^{\prime}\end{array}$ & $\begin{array}{l}70^{\circ} 25^{\prime} \\
70^{\circ} 25^{\prime} \\
70^{\circ} 25^{\prime} \\
70^{\circ} 25^{\prime} \\
70^{\circ} 25^{\prime} \\
70^{\circ} 25^{\prime} \\
70^{\circ} 25^{\prime} \\
70^{\circ} 25^{\prime} \\
70^{\circ} 25^{\prime} \\
70^{\circ} 25^{\prime} \\
70^{\circ} 11^{\prime} \\
70^{\circ} 25^{\prime}\end{array}$ & $\begin{array}{l}\text { Humpback whale: Megaptera novaeangliae, } 1 \\
\text { Humpback whale, l. } \\
\text { Blows, unidentified. } \\
\text { Blows, unidentified. } \\
\text { Blows, unidentified. } \\
\text { Blows, unidentified. } \\
\text { Blows, unidentified. } \\
\text { Blow, unidentified. } \\
\text { Blow, unidentified. } \\
\text { Blow, unidentified. } \\
\text { Whales: unidentified, } 4 . \\
\text { Whales: unidentified, } 11 .\end{array}$ \\
\hline
\end{tabular}


Appendix 5

Coral Reef Fishes Sighted at Castle Rock, Bermuda August 10, 1978

\begin{tabular}{|c|c|c|}
\hline Common Name & Relative Sightin & g Frequency \\
\hline purple mouth moray & Gyanothorax vicinus & 1 \\
\hline fairy basslet & Gramma lareto & 1 \\
\hline Jew fish & Epinephelus itajata & 1 \\
\hline blue striped grunt & Haemulon sp. & 1 \\
\hline pork fish & Anisotremus virginicus & 2 \\
\hline goat fish & Pseudupeneus sp. & 1 \\
\hline silver porgy & Diplodus argenteus & 1 \\
\hline peacock flounder & Bothus Iunatus & 1 \\
\hline blue head wrasse & Thalassoma bifasciatum & 3 \\
\hline angelfish, queen & Holacanthus ciliaris & 3 \\
\hline angelfish, blue & Holacanthus bermudensis (Goode) & 3 \\
\hline queen triggerfish & Balistes vetula (Linnaeus) & 2 \\
\hline blue tang & Acanthurus coeruleus & 2 \\
\hline smooth trunk fish & Lactophrys triqueter & 4 \\
\hline spotted trunk fish & Lactophrys bicaudalis (Iinnaeus) & 1 \\
\hline jolthead porgy & Calamus bajonado & 2 \\
\hline sergeant major & Abudefduf saxatilis & 7 \\
\hline cocoa damselfish & Eupomacentrus variabilis & 1 \\
\hline stoplight parrotfish & Sparisoma viride & 4 \\
\hline red band parrotfish & Sparisoma aurofrenatum (Valenciennes) & 1 \\
\hline Molly Miller & Blennius cristatus (Linnaeus) & 1 \\
\hline grey snapper & Iutjanus griseus & $\overline{1}$ \\
\hline butterfly fish & Chaetodon sp. & 1 \\
\hline queen parrotfish & Scarus vetula & 1 \\
\hline blue parrotfish & Scarus coeruleus & 2 \\
\hline French grunt & Haemulon flavolineatum & 1 \\
\hline four-eye butterfly fish & Chaetodon capistratus & 1 \\
\hline longsnout butterfly fish & Prognathodes aculeatus & 1 \\
\hline razorfish & Hemipteronotus sp. & 1 \\
\hline rainbow parrotfish & Scarus guacamaia & 1 \\
\hline
\end{tabular}


Appendix 6 .

W-4l Otter Trawl Species Rosters \& Diversities

Trawl \# Name

No. Length/Wt.

28 July 78 leopard skate

$39^{\circ} 57^{\prime} \mathrm{N}$ spotted hake

$69^{\circ} 41^{\prime} \mathrm{W}$ four spotted flounder

(1) armored sea robin

goosefish

hermit crab

crab

lobster

shrimp

starfish

starfish

starfish
Rajia garmani

Trophycis regius

Paralichthys oblongus

Peristedion miniatum

Iophius americanus

Eupagurus bernhardus

Cancer borealis

Homarus americanus

Munida valida

Henricia genus

Leptychaster arcticus

Ctenodiscus arcticus
$1 \quad 13$ oz

228 oz

1294 oz

$18 \mathrm{oz}$

$1104 \mathrm{oz}$

1

22

2

21

5

17

3

Diversity Index $=6.15$

20 Aug 78 thorny skate $44^{\circ} 34^{\prime} \mathrm{N}$ long horn sculpon

$59^{\circ} 34^{\prime} \mathrm{W}$ yellow tail flounder

American plaice

(2) skate egg cases

hermit crab

purple sun star

basket star

cushion star

blood stars

starfish, others

grey brittle stars and

black-striped brittle star

brittle star others

orange striped sea cucumbers

sand dollar

sea urchin
Raja radiata $1130 \mathrm{oz}$

Myoxocephalus octodecemspinosus $1 \quad 8 \mathrm{oz}$ Limanda ferruginea $6 \quad 48 \mathrm{oz}$

Hyppoglossoides platessoides $\quad 15 \quad 104 \mathrm{oz}$

Pagurus bernhardas 2

Solaster endeca 1

Gorgonocephalus arcticus 3

Hippasteria phrygiana 1

Asterias vulgaris 7

2

53

Ophioderma sp.

Qphiopholis aculeata

2

4

2

159

80

Echinarachnius parma

Strongylocentrotus drobachiensis 9

Diversity Index $=5.49$

22 Aug 78 American pläice

$44^{\circ} 34^{\prime} \mathrm{N}$

$64^{\circ} 00^{\prime} \mathrm{W}$

(3) skate

starfish

brittle star

purple sun star

golden bordered star

sea cucumber
Hyppoglossoides platessoides $\quad 340$ unidentified

Asterias sp.

unidentified

Solaster endeca (Linnaeus)

Ieptosynapta sp.
340
2

130

21

2

Diversity Index $=1.84$ 


\section{Appendix 7}

W-4I Hydrographic Data Log

\begin{tabular}{|c|c|c|c|c|c|c|c|c|c|c|}
\hline $\begin{array}{c}\text { Sta } \\
\#\end{array}$ & $\begin{array}{l}\text { Date } \\
\mathrm{d} / \mathrm{m}\end{array}$ & Time & $\begin{array}{l}\text { Posi } \\
\text { Lat }(\mathrm{N})\end{array}$ & $\begin{array}{l}\text { tion } \\
\text { Long (W) }\end{array}$ & $\begin{array}{c}\text { Depth } \\
\text { (M) }\end{array}$ & $\underset{\mathrm{C}}{\text { Temp. }}$ & $\begin{array}{l}\text { Salinity } \\
/ \infty 0\end{array}$ & $\begin{array}{r}\mathrm{O}_{2} \\
\text { ppm }\end{array}$ & $\begin{array}{c}\mathrm{PO}_{4}-\mathrm{P} \\
\mu \mathrm{g}-\mathrm{aT} / \mathrm{L}\end{array}$ & $\begin{array}{c}\mathrm{NO}_{3}-\mathrm{N} \\
\mu g-\mathrm{aT} / \mathrm{I}\end{array}$ \\
\hline 1 & 28 July & 1200 & $40^{\circ} 06^{\prime}$ & $69^{\circ} 51^{\prime}$ & $\begin{array}{r}0 \\
13 \\
36 \\
66 \\
100\end{array}$ & $\begin{array}{r}20.31 \\
19.85 \\
8.86 \\
8.10 \\
9.05\end{array}$ & $\begin{array}{l}34.04 \\
34.09 \\
32.79 \\
33.85 \\
35.29\end{array}$ & $\begin{array}{l}5.26 \\
5.40 \\
5.88 \\
5.60 \\
4.68\end{array}$ & $\begin{array}{l}.0286 \\
.0536 \\
.0203 \\
.0286 \\
-\end{array}$ & $\begin{array}{r}14.29 \\
2.86 \\
2.86 \\
0.71 \\
\end{array}$ \\
\hline 2 & 29 JuIy & 0000 & $39^{\circ} 49^{\prime}$ & $69^{\circ} 40^{\prime}$ & $\begin{array}{r}0 \\
100 \\
200 \\
300 \\
400\end{array}$ & $\begin{array}{r}21.71 \\
15.02 \\
10.48 \\
8.38 \\
6.52\end{array}$ & $\begin{array}{l}33.83 \\
37.27 \\
33.85 \\
36.05 \\
34.90\end{array}$ & $\begin{array}{l}5.04 \\
3.99 \\
3.37 \\
3.29 \\
4.20\end{array}$ & $\begin{array}{l}.0225 \\
.0162 \\
.0950 \\
.0455 \\
.0455\end{array}$ & $\begin{array}{r}0.36 \\
2.14 \\
13.57 \\
17.14 \\
10.00\end{array}$ \\
\hline 3 & $29 \mathrm{July}$ & 2040 & $38^{\circ} 33^{\prime}$ & $70^{\circ} 08^{\prime}$ & $\begin{array}{r}0 \\
26 \\
200\end{array}$ & $\begin{array}{l}24.73 \\
22.96 \\
13.93\end{array}$ & $\begin{array}{l}36.79 \\
36.05 \\
35.71\end{array}$ & $\begin{array}{l}4.88 \\
4.88 \\
3.45\end{array}$ & $\begin{array}{l}.0286 \\
.0620 \\
.0781\end{array}$ & $\begin{array}{l}0.00 \\
0.00 \\
6.43\end{array}$ \\
\hline 4 & $30 \mathrm{July}$ & 0207 & $38^{\circ} 33^{\prime}$ & $70^{\circ} 08^{\prime}$ & $\begin{array}{r}0 \\
27 \\
200 \\
400\end{array}$ & $\begin{array}{r}24.53 \\
22.68 \\
12.29 \\
7.96\end{array}$ & $\begin{array}{l}35.47 \\
33.90 \\
35.59 \\
35.04\end{array}$ & $\begin{array}{l}4.64 \\
5.15 \\
3.50 \\
3.42\end{array}$ & $\begin{array}{l}.0039 \\
.0390 \\
.0370 \\
.0039\end{array}$ & $\begin{array}{r}0.00 \\
0.00 \\
42.86 \\
7.80\end{array}$ \\
\hline 5 & $30 \mathrm{Juzly}$ & 0812 & $38^{\circ} 31^{\prime}$ & $70^{\circ} 11{ }^{\prime}$ & $\begin{array}{r}0 \\
30 \\
200 \\
400\end{array}$ & $\begin{array}{c}23.96 \\
23.12 \\
13.4 \\
8.39\end{array}$ & $\begin{array}{l}35.21 \\
36.36 \\
35.91 \\
35.09\end{array}$ & $\begin{array}{l}4.63 \\
4.79 \\
3.58 \\
3.42\end{array}$ & $\begin{array}{l}.0740 \\
.0330 \\
.0580 \\
.0870\end{array}$ & $\begin{array}{c}7.14 \\
0 \\
.71 \\
12.46\end{array}$ \\
\hline 6 & $30 \mathrm{JulJ}$ & 1430 & $38^{\circ} 33^{\prime}$ & $70^{\circ} 08^{\prime}$ & $\begin{array}{r}0 \\
21 \\
200 \\
400\end{array}$ & $\begin{array}{r}24.62 \\
23.38 \\
12.38 \\
7.75\end{array}$ & $\begin{array}{l}28.61 \\
25.77 \\
29.91\end{array}$ & $\begin{array}{l}5.10 \\
5.12 \\
3.66 \\
3.66\end{array}$ & $\begin{array}{l}.000 \\
.0245 \\
.0290 \\
.0330\end{array}$ & $\begin{array}{r}.71 \\
0.00 \\
11.79 \\
7.86\end{array}$ \\
\hline 7 & 1 Aug & 2020 & $36^{\circ} 56^{\prime}$ & $66^{\circ} 25^{\prime}$ & $\begin{array}{r}0 \\
40 \\
100 \\
200\end{array}$ & $\begin{array}{l}28.48 \\
27.62 \\
23.50 \\
19.21\end{array}$ & $\begin{array}{l}34.25 \\
32.41 \\
31.75 \\
26.15\end{array}$ & $\begin{array}{l}5.73 \\
6.03 \\
4.79 \\
3.47\end{array}$ & $\begin{array}{l}.0094 \\
.0039 \\
.0329 \\
.0203\end{array}$ & $\begin{array}{r}0.00 \\
.71 \\
0.00 \\
1.50\end{array}$ \\
\hline 8 & 4 Aug & 2145 & $34^{\circ} 00^{\prime}$ & $66^{\circ} 31^{\prime}$ & $\begin{array}{r}0 \\
40 \\
110 \\
200 \\
400\end{array}$ & $\begin{array}{l}26.90 \\
22.66 \\
18.63 \\
18.14 \\
17.33\end{array}$ & $\begin{array}{l}36.13 \\
36.54 \\
36.44 \\
36.65 \\
\end{array}$ & $\begin{array}{l}5.98 \\
7.15 \\
6.85 \\
6.18 \\
5.71\end{array}$ & $\begin{array}{l}.0240 \\
.0203 \\
.0162\end{array}$ & $\begin{array}{l}0.00 \\
2.14 \\
0.00 \\
+\end{array}$ \\
\hline 9 & 11 Aug & 2115 & $34^{\circ} 07^{\prime}$ & $64^{\circ} 33^{\prime}$ & $\begin{array}{r}0 \\
120 \\
200 \\
400\end{array}$ & $\begin{array}{l}27.14 \\
18.48 \\
18.19 \\
17.93\end{array}$ & $\begin{array}{l}35.30 \\
35.50 \\
35.38 \\
35.50\end{array}$ & $\begin{array}{l}2.69 \\
3.12 \\
3.27 \\
3.35\end{array}$ & $\begin{array}{l}.000 \\
.035 \\
.000 \\
.000\end{array}$ & $\begin{array}{l}0.00 \\
0.00 \\
0.00 \\
0.00\end{array}$ \\
\hline & ? & & & & $-45-$ & & & & & \\
\hline
\end{tabular}


(W-4I Hydrographic Data Log Cont.)

\begin{tabular}{|c|c|c|c|c|c|c|c|c|c|c|}
\hline $\begin{array}{c}\text { Sta } \\
\#\end{array}$ & $\begin{array}{r}\text { Date } \\
\mathrm{d} / \mathrm{m}\end{array}$ & Time & $\begin{array}{r}\text { Pos } \\
\text { Lat }(\mathrm{N})\end{array}$ & $\begin{array}{l}\text { Eion } \\
\text { Long (W) }\end{array}$ & $\begin{array}{c}\text { Depth } \\
\text { (M) }\end{array}$ & $\underset{\mathrm{C}}{\text { Temp. }}$ & $\begin{array}{c}\text { Salinity } \\
\%\end{array}$ & $\begin{array}{r}\mathrm{O}_{2} \\
\mathrm{ppm}\end{array}$ & $\begin{array}{r}\mathrm{PO}_{4}-\mathrm{P} \\
\mu \mathrm{g}-\mathrm{aT} / \mathrm{L}\end{array}$ & $\begin{array}{c}\mathrm{NO}_{3}-\mathrm{N} \\
\mathrm{Kg}-\mathrm{aT} / \mathrm{L}\end{array}$ \\
\hline 10 & $14 \mathrm{Aug}$ & 1355 & $37^{\circ} 47^{\prime}$ & $62^{\circ} 35^{\prime}$ & $\begin{array}{r}0 \\
55 \\
200 \\
400\end{array}$ & $\begin{array}{l}28.55 \\
28.59 \\
24.98 \\
19.34\end{array}$ & $\begin{array}{l}35.09 \\
35.17 \\
\overline{35.42}\end{array}$ & $\begin{array}{l}4.27 \\
4.21 \\
3.86 \\
3.64\end{array}$ & $\begin{array}{l}.0245 \\
.0039 \\
.0203\end{array}$ & $\begin{array}{l}1.07 \\
\frac{0.00}{3.21}\end{array}$ \\
\hline 11 & 14 Aug & 2016 & $37^{\circ} 43^{\prime}$ & $62^{\circ} 29^{\prime}$ & $\begin{array}{r}0 \\
55 \\
200 \\
400\end{array}$ & $\begin{array}{l}28.52 \\
25.66 \\
19.94\end{array}$ & $\begin{array}{l}35.32 \\
35.30 \\
35.55 \\
35.67\end{array}$ & $\begin{array}{l}4.20 \\
4.21 \\
3.90 \\
4.21\end{array}$ & $\begin{array}{l}.0290 \\
.0703 \\
.0162 \\
.0290\end{array}$ & $\begin{array}{l}0.00 \\
1.43 \\
1.43 \\
2.86\end{array}$ \\
\hline 12 & 15 Aug & 0206 & $37^{\circ} 42^{\prime}$ & $62^{\circ} 33^{\prime}$ & $\begin{array}{r}0 \\
55 \\
200 \\
400\end{array}$ & $\begin{array}{l}28.52 \\
30.07 \\
23.12 \\
18.56\end{array}$ & $\begin{array}{l}35.11 \\
35.05 \\
35.71 \\
35.57\end{array}$ & $\begin{array}{l}4.30 \\
4.35 \\
3.80 \\
4.29\end{array}$ & $\begin{array}{l}.0000 \\
.0300 \\
.0200\end{array}$ & $\frac{1.43}{2.14}$ \\
\hline 13 & I5 Aug & 0806 & $37^{\circ} 46^{\prime}$ & $62^{\circ} 36^{\prime}$ & $\begin{array}{r}0 \\
75 \\
200 \\
400\end{array}$ & $\begin{array}{l}28.55 \\
28.23 \\
22.89 \\
18.45\end{array}$ & $\begin{array}{l}35.30 \\
35.25 \\
35.94 \\
35.30\end{array}$ & $\begin{array}{l}3.99 \\
3.92 \\
4.12 \\
4.49\end{array}$ & $\begin{array}{l}.0710 \\
.1500 \\
.0710\end{array}$ & $\begin{array}{l}1.80 \\
0.71 \\
1.07 \\
4.30\end{array}$ \\
\hline 14 & $17 \mathrm{Aug}$ & 2035 & $41^{\circ} 38^{\prime}$ & $61^{\circ} 42^{\prime}$ & $\begin{array}{r}0 \\
40 \\
100 \\
200 \\
400\end{array}$ & $\begin{array}{r}23.98 \\
17.99 \\
15.43 \\
12.76 \\
8.51\end{array}$ & $\begin{array}{l}33.94 \\
34.59 \\
34.92 \\
34.79 \\
32.60\end{array}$ & $\begin{array}{l}4.72 \\
5.47 \\
5.24 \\
6.61 \\
5.87\end{array}$ & $\begin{array}{l}.0330 \\
.0039 \\
.0203 \\
.0290 \\
.0162\end{array}$ & $\begin{array}{r}1.43 \\
0.00 \\
5.70 \\
3.57 \\
10.20\end{array}$ \\
\hline
\end{tabular}

